\title{
Rintisan Pengembangan Pendidikan Karakter di Satuan Pendidikan
}

\author{
Sutjipto \\ Kemdikbud, e-mail: sutjipto.55@gmail.com
}

\begin{abstract}
Abstrak: Studi ini menggambarkan model pengembangan nilai-nilai pendidikan karakter pada satuan pendidikan rintisan tahun 2010 yang diselenggarakan oleh Pusat Kurikulum. Studi berbentuk kajian deskriptif dengan analisis wacana kritis, di mana data utama diolah berdasarkan program kegiatan, pelaksanaan kegiatan, dan laporan hasil kegiatan di seluruh satuan pendidikan rintisan implementasi karakter bangsa. Informasi dikumpulkan melalui berbagai sumber seperti dokumentasi, fokus grup diskusi, dan keterlibatan langsung peneliti dalam kegiatan rintisan. Teknik analisis data yang dipergunakan, yaitu deskripsi, dan interpretasi. Hasil kajian menunjukkan bahwa satuan pendidikan rintisan umumnya berhasil menerapkan nilai-nilai karakter yang dapat diamati secara kasat mata langsung (tangible) seperti religius, peduli lingkungan (bersih, rapi, aman, nyaman, indah, teduh dan sejuk), disiplin, empati, kerja sama, sopan santun, ramah, senyum, salam, dan sapa. Keberhasilan tersebut diperoleh dari adanya tahapan kegiatan yang terorganisir, terkoordinasi, dan terkondisi, melalui sosialisasi kebijakan pengembangan model dan pelatihan, pelaksanaan magang di satuan pendidikan pengalaman terpetik (best practice), penyusunan kurikulum tingkat satuan pendidikan, dan supervisi.
\end{abstract}

Kata kunci: kesadaran, komitmen, penanaman nilai, dan pembudayaan.

\begin{abstract}
This study describes the development model the values of character education in the educational unit stub year 2010 organized by the Curriculum Centre. Studies descriptive studies shaped by critical discourse analysis, where the main data processed by the program activities, implementation activities, and reports results of activities throughout the pilot implementation of character education unit of the nation. Information collected through various sources such as documentation, focus group discussion, and direct involvement of researchers in pilot activities. Data analysis techniques are used, namely description, and interpretation. The study results indicate that the pilot general education units successfully apply character values that can be observed by naked eye directly (tangible) such as religious, caring environment (clean, neat, safe, comfortable, beautiful, shady and cool), discipline, empathy, employment same time, polite, friendly, smiling, greeting, and sapa. The success is derived from the phases of activity that is organized, coordinated, and conditioned, through the socialization model development and training policies, the implementation of internships in the education unit terpetik experience (best practice), the preparation level of the education curriculum, and supervision.
\end{abstract}

Key words: awareness, commitment, investment values, and acculturation.

\section{Pendahuluan}

Mengapa pendidikan karakter perlu dikembangkan dan diimplementasikan di satuan pendidikan? Pertama, saat ini pemerintah Indonesia melalui Menteri Pendidikan Nasional telah mengeluarkan kebijakan untuk mengintegrasikan pendidikan karakter ke dalam kurikulum, mulai dari jenjang prasekolah, pendidikan dasar, pendidikan menengah baik pada jalur pendidikan formal maupun nonformal, hingga perguruan tinggi. Kedua, pendidikan karakter membekali peserta didik dengan berbagai nilai yang bermanfaat bagi kehidupannya masa kini dan masa yang akan datang. Pentingnya pendidikan karakter diungkapkan oleh Mendiknas sebagaimana yang dimuat dalam situs antaranews.com, 15/5/2010 bahwa pendidikan karakter menjadi suatu keharusan karena pendidikan tidak hanya menjadikan peserta didik menjadi cerdas, juga mempunyai budi pekerti dan sopan santun sehingga keberadaannya sebagai anggota masyarakat menjadi bermakna baik bagi dirinya maupun orang lain.

Dari pernyataan menteri tersebut dapat dimaknai bahwa kebijakan penerapan pendidikan 
karakter akan menjadi salah satu sasaran prioritas di Kementerian Pendidikan Nasional karena dianggap menyangkut kekuatan akhlak moral seseorang atau tingkah laku peserta didik. Pendidikan karakter menjadi koridor bagi terwujudnya sikap mental (mental attitude) yang kuat dan positif. Sikap mental sebagai unsur penggerak dari berbagai jenis dan bentuk kelakuan peserta didik dapat diartikan sebagai keadaan mental dalam jiwa dari diri untuk memberikan reaksi terhadap lingkungan, baik lingkungan sosial maupun lingkungan alam. Sikap mental itu sendiri belum merupakan konsep yang berwujud tetapi masih merupakan predisposisi dari berbagai kelakuan atau tindakan yang disebut mentalitas peserta didik. Perilaku peserta didik tersebut dipengaruhi secara langsung oleh keseluruhan dari isi serta kemampuan alam pikiran atau jiwa mereka dalam menanggapi lingkungannya. Mentalitas peserta didik merupakan suatu nilai pendidikan karakter yang harusnya ditumbuhkembangkan dalam dirinya secara perorangan, dan berpedoman pada orientasi nilai (value orientation) pendidikan karakter yang terikat oleh struktur nilai yang mengakar dan melembaga di dalam masyarakatnya.

Orientasi nilai adalah nilai-nilai yang dijadikan acuan atau rujukan bagi peserta didik untuk berpikir dan bertindak baik secara individu maupun kolektif. Orientasi nilai-nilai pendidikan karakter pada hakikatnya menguraikan enam masalah pokok dalam kehidupan kemasyarakatan, yaitu nilai yang berkaitan dengan permasalahan tentang hakikat hidup, karya, kedudukan dalam ruang dan waktu, hubungan dengan Tuhan, hubungan dengan alam dan sekitarnya, dan hubungan dengan sesamanya. Nilai karakter pada frasa pendidikan mengarah pada pembentukan budaya satuan pendidikan, yaitu nilai-nilai yang melandasi perilaku, tradisi, kebiasaan keseharian, dan simbol-simbol yang dipraktikkan oleh semua komunitas satuan pendidikan, dan masyarakat sekitar satuan pendidikan. Dengan demikian, budaya satuan pendidikan merupakan ciri khas, karakter atau watak, dan citra satuan pendidikan di mata masyarakat luas.

Tingkat orientasi masing-masing peserta didik atau masyarakat yang dilandasi nilai-nilai pendidikan karakter tertentu berbeda satu dengan lainnya. Hal ini terjadi karena adanya saling keterkaitan dengan nilai-nilai lain yang berlaku di masyarakatnya. Tingkatan orientasi nilai-nilai karakter yang diyakini oleh peserta didik, komunitas satuan pendidikan dan masyarakat sekitar tersebut sesungguhnya dapat diubah, diarahkan, ditanamkan, dibiasakan, dan dibudayakan. Untuk mengubah orientasi nilai karakter yang positif tersebut diperlukan suatu proses pembelajaran melalui pembiasaan dan pembudayaan yang dilandasi dengan tekat keteladanan. Di samping itu, komitmen seluruh komunitas satuan pendidikan untuk melaksanakannya secara sungguh-sungguh penting di ketengahkan dalam menggapai keberhasilan maupun ketidakberhasilan.

Berdasarkan uraian tersebut di atas, muncullah tuntutan untuk mengkonsepkan kembali pengembangan model nilai-nilai pendidikan karakter yang bertumpu pada konsep manajemen berbasis sekolah/satuan pendidikan (MBS). Dalam arti bahwa masing-masing satuan pendidikan diberi kesempatan yang harus digunakan untuk menanamkan nilai-nilai pendidikan karakter secara inovatif dan kreatif, dan menerapkannya dalam praktik belajar mengajar sehari-hari kepada peserta didik.

Penekanan pada pendekatan pengelolaan dimaksudkan agar mutu pendidikan karakter ditingkatkan melalui penguatan kemampuan setiap satuan pendidikan untuk menerapkan strategi khusus dalam seluruh aktivitas pembelajaran secara sendiri-sendiri. Melalui manajemen berbasis sekolah, misalnya, pimpinan satuan pendidikan diberi tanggungjawab sepenuhnya untuk melaksanakan pendidikan karakter secara optimal dengan cara memilih dan memutuskan nilai-nilai apa yang terbaik untuk diimplementasikan di masing-masing satuan pendidikan. Hal ini sejalan pula dengan salah satu butir kesepakatan dari sarasehan nasional pengembangan pendidikan budaya dan karakter tanggal 14 Januari 2010 bertempat di Hotel Bumikarsa, Komplek Bidakara, Jakarta, yaitu bahwa "Pendidikan budaya dan karakter bangsa harus dikembangkan secara komprehensif sebagai proses pembudayaan. Oleh karena itu, pendidikan karakter dan kebudayaan secara kelembagaan 
perlu diwadahi secara utuh" dalam sistem persekolahan (cetak miring tambahan penulis).

Sistem perintisan dikembangkan atas asumsi bahwa model kurikulum pendidikan karakter mampu memberikan hasil yang lebih baik daripada model lainnya. Hal ini karena diterapkan secara terbatas di sejumlah satuan pendidikan, dan adanya intervensi. Terbatas dalam arti bahwa pada tahun 2010 hanya diterapkan di 16 kabupaten/kota dari 16 provinsi dengan jumlah satuan pendidikan sebanyak 125 satuan pendidikan. Tiap kabupaten/kota rata-rata terdapat 7 sampai dengan 8 satuan pendidikan yang ditunjuk menjadi model rintisan.

Intervensi dilakukan sebagai upaya advokasi dan pendampingan kepada satuan pendidikan rintisan dalam bentuk ceramah, diskusi, dan workshop serta pemaparan hasil. Kegiatan difasilitasi tenaga profesional dari Pusat Kurikulum mulai dari penyusunan desain kurikulum, rencana kerja satuan pendidikan dalam mengembangkan dan mengimplementasikan seluruh komponen/ aspek kurikulum sampai penyusunan dokumen kurikulum, silabus dan rencana pelaksanaan pembelajaran (RPP), beserta lembar kegiatan pembelajaran lainnya (yang diperlukan). Dengan demikian, kurikulum yang dihasilkan akan sesuai dengan kebutuhan, potensi, dan kondisi daerah maupun satuan pendidikan.

Tujuan dikembangkannya model ini yaitu untuk mewujudkannya nilai-nilai pendidikan karakter pada komunitas satuan pendidikan yang terefleksi dalam budaya satuan pendidikan dan budaya kelas pembelajaran yang dapat dijadikan sebagai rujukan pengalaman terpetik (best practice). Secara khusus kegiatan tersebut bertujuan agar satuan pendidikan dapat: 1) mengembangkan/menyusun/memperkaya kurikulum tingkat satuan pendidikan (KTSP) yang memuat nilai-nilai pendidikan karakter; dan 2) menyeleng-garakan pendidikan bermuatan nilainilai pendidikan karakter yang terikat baik secara nasional maupun lokal dengan struktur nilai yang mengakar dan melembaga dalam masyarakat sekitar.

\section{Kajian Teori dan Pembahasan} Pengembangan Model Pendidikan Karakter

Terdapat beberapa pengertian tentang model.
Departemen P dan K (1984) menyebutkan model adalah pola, contoh, acuan, atau ragam dari sesuatu yang akan dibuat atau dihasilkan. Menurut Simamarta (1983) (di situs kadipatentecnology.blogspot.com) model adalah abstraksi dari sistem sebenarnya, dalam gambaran yang lebih sederhana serta mempunyai tingkat persentase yang bersifat menyeluruh, atau model adalah abstraksi dari realitas dengan hanya memusatkan perhatian pada beberapa sifat dari kehidupan sebenarnya.

Model yang dimaksud dalam risalah ini merujuk pendapat dari Departemen $\mathrm{P}$ dan $\mathrm{K}$ (1984), yaitu suatu pola, contoh, acuan, atau ragam dari sesuatu yang akan dihasilkan. Artinya, bahwa pengembangan model pendidikan karakter sebagai rintisan pada satuan pendidikan ini nantinya akan dijadikan contoh atau acuan bagi satuan pendidikan lainnya di kabupaten/kota itu, atau kabupaten/kota sekitarnya. Satuan pendidikan rintisan akan dijadikan sebagai model "pengalaman terpetik" (best practice) bagi satuan pendidikan lainnya dalam penyusunan kurikulum yang bermuatan nilai-nilai pendidikan karakter.

Kajian penulis terhadap seperangkat dokumen yang telah dihasilkan (desain/rancangan kegiatan maupun laporan-laporan tiap langkah kegiatan) dapat dinyatakan bahwa ditinjau dari fungsinya, model rintisan yang dikembangkan merupakan model normatif (di unduh dari situs damandiri.or.id), yaitu suatu model yang menyediakan jawaban yang baik terhadap salah satu persoalan peserta didik, masyarakat, dan bangsa. Dalam mengembangkan model ini nantinya akan memberi rekomendasi tindakantindakan yang perlu diambil oleh pemangku kepentingan pendidikan baik di tingkat pusat maupun daerah berkaitan dengan pola penyusunan, perancangan, penerapan, dan evaluasi pendidikan karakter di satuan pendidikan, baik pada jalur pendidikan formal maupun pendidikan nonformal.

Ditinjau dari pendekatannya, paling tidak ada dua pendekatan yang dianut dalam pengembangan model kurikulum pendidikan karakter sebagai rintisan ini, yaitu: 1) pendekatan yang berdasarkan kurikulum itu pada "social functions" (di unduh dari situs thefreedictionary.com), yakni lapanganlapangan hidup peserta didik sebagai pusat 
perbuatan-perbuatan mereka - sebuah kesempatan yang diatur sebagai fungsi sosial-, dan 2) pendekatan dengan mengambil norma-norma pokok sekitar dari kebutuhan peserta didik, dari problema-problema yang dihadapi peserta didik dalam kehidupannya.

Di samping itu, perumusan pengembangan model pendidikan karakter ini dilakukan menggunakan metodologi pembelajaran sosial (social learning), yang berdasarkan kerangka konsepsi dan praktik nyata pendidikan karakter di masing-masing satuan pendidikan. Perumusan model dilakukan dengan pola advokasi dan pendampingan dengan substansi yang mengkombinasikan kebijakan, konsepsi, pendekatan teoritik dan praktik penyusunan dan pelaksanaan KTSP secara simultan untuk memperoleh rumusan komprehensif pengembangan model pendidikan karakter.

Menggunakan metode sebagaimana diungkap di atas, kegiatan pengembangan model dilakukan secara bertahap, yang mencakup 4 tahapan kegiatan. Setiap tahapan kegiatan selalu dimulai dari paparan, kajian dan diskusi, kontekstualisasi konsep dan pengalaman praktisi di dalam konteks satuan pendidikan, workshop penyusunan kurikulum, dan supervisi pelaksanaan kurikulum berdasarkan konteks dan muatan pendidikan karakter sebagai rintisan pada 125 satuan pendidikan di 16 kabupaten/kota dari 16 provinsi.

\section{Pendidikan Karakter}

Pendidikan karakter mengandung dua kata, yaitu pendidikan dan karakter. Ditinjau dari sudut etimologi, kata "karakter" atau dalam bahasa Inggris disebut "character" dan bahasa Yunani "charassein" (Guralnik, 1986), artinya mengukir hingga terbentuk sebuah pola, dapat pula diartikan sebagai "pola perilaku moral individu". Karenanya, untuk mendidik anak agar memiliki karakter diperlukan proses 'mengukir', yakni pengasuhan dan pendidikan yang tepat. Menurut Wynne (di unduh dari situs karakterbangkit. blogspot.com), istilah karakter diambil dari bahasa Yunani pula yang berarti 'to mark' atau menandai. Istilah ini lebih fokus pada tindakan atau tingkah laku. Wynne mengatakan bahwa ada dua pengertian tentang karakter. Pertama, ia menunjukkan bagaimana seseorang bertingkah laku. Apabila seseorang berperilaku tidak jujur, kejam, atau rakus, tentulah orang tersebut memanifestasikan perilaku buruk/jelek. Sebaliknya, apabila seseorang berperilaku jujur, suka menolong, tentulah orang tersebut memanifestasikan karakter mulia. Kedua, istilah karakter erat kaitannya dengan 'personality'. Seseorang baru bisa disebut 'orang yang berkarakter' (a person of character) apabila tingkah lakunya sesuai kaidah moral.

Karakter adalah watak, tabiat, akhlak, atau kepribadian seseorang yang terbentuk dari hasil internalisasi berbagai kebajikan (virtues) yang diyakini dan digunakan sebagai landasan untuk cara pandang, berpikir, bersikap, dan bertindak. Kebajikan terdiri atas sejumlah nilai, moral, dan norma, seperti jujur, berani bertindak, dapat dipercaya, dan hormat kepada orang lain (Pusat Kurikulum, 2010a). Dalam kamus besar bahasa Indonesia tidak memuat kata karakter, namun yang ada adalah bermakna sebagai bawaan, hati, jiwa, kepribadian, berperilaku, tabiat, dan kata 'watak' dalam arti sifat batin manusia yang mempengaruhi segenap pikiran dan tingkah lakunya (Pusat Bahasa, 2005). Watak menurut Soedarsono (2004) dapat diubah. Watak merupakan pemicu atau pemberi "arah" atas tindakan-tindakan perilaku seseorang.

Karakter baik berarti individu memiliki pengetahuan tentang potensi dirinya, yang ditandai dengan nilai-nilai seperti reflektif, percaya diri, rasional, logis, kritis, analitis, kreatif dan inovatif, mandiri, hidup sehat, bertanggung jawab, cinta ilmu, sabar, berhati-hati, rela berkorban, pemberani, dapat dipercaya, jujur, menepati janji, adil, rendah hati, malu berbuat salah, pemaaf, berhati lembut, setia, bekerja keras, tekun, ulet/ gigih, teliti, berinisiatif, berpikir positif, disiplin, antisipatif, inisiatif, visioner, bersahaja, bersemangat, dinamis, hemat/efisien, menghargai waktu, pengabdian/dedikatif, pengendalian diri, produktif, ramah, cinta keindahan (estetis), sportif, tabah, terbuka, dan tertib.

Individu yang berkarakter baik merupakan seseorang yang berusaha melakukan hal-hal yang terbaik terhadap Tuhan YME, dirinya, sesamanya, lingkungannya, bangsa dan negaranya serta dunia internasional pada umumnya dengan 
mengoptimalkan potensi (pengetahuan) dirinya dan disertai dengan kesadaran, emosi dan motivasinya serta perasaannya. Seseorang yang dapat dipercaya, bertanggung jawab, hormat, adil, peduli, empati, mengendalikan diri, dan, di atas segalanya, dia adalah warga negara yang berkarakter baik yang mematuhi hukum dan bermain menurut aturan. Karakter yang baik terdiri dari mengetahui yang baik, menginginkan yang baik, dan melakukan yang baik (Lickona, 1992)

Dari lima pengertian tersebut, dapat dikatakan bahwa karakter adalah nilai-nilai yang khas-baik (tahu nilai kebaikan, mau berbuat baik, nyata berkehidupan baik, dan berdampak baik terhadap lingkungan) yang terpateri dalam diri dan terejawantahkan dalam perilaku. Karakter berkaitan dengan sikap, pola perilaku dan atau kebiasaan yang mempengaruhi interaksi seseorang terhadap Tuhan dan lingkungannya. Karakter menentukan sikap, perkataan dan tindakan. Hampir setiap masalah dan kesuksesan yang dicapai seseorang ditentukan oleh karakter yang dimiliki. Karakter secara koheren memancar dari hasil olah pikir, olah hati, olah raga, serta olah rasa dan karsa seseorang atau sekelompok orang. Karakter merupakan ciri khas seseorang atau sekelompok orang yang mengandung nilai, kemampuan, kapasitas moral, dan ketegaran dalam menghadapi kesulitan dan tantangan (Pemerintah RI, 2010).

Sementara itu, menurut Suyanto (di unduh dari situs mandikdasmen.depdiknas.go.id) karakter adalah cara berpikir dan berperilaku yang menjadi ciri khas tiap individu untuk hidup dan bekerja sama, baik dalam lingkup keluarga, masyarakat, bangsa dan negara. Individu yang berkarakter baik adalah individu yang bisa membuat keputusan dan siap mempertanggungjawabkan tiap akibat dari keputusan yang ia buat. Selanjutnya, masih menurut Suyanto, terdapat sembilan pilar karakter yang berasal dari nilai-nilai luhur universal, yaitu: 1) karakter cinta Tuhan dan segenap ciptaan-Nya; 2) kemandirian dan tanggungjawab; 3) kejujuran/amanah, diplomatis; 4) hormat dan santun; 5) dermawan, suka tolong-menolong dan gotong royong/kerja sama; 6) percaya diri dan pekerja keras; 7) kepemimpinan dan keadilan; 8) baik dan rendah hati, dan; 9) karakter toleransi, kedamaian, dan kesatuan.

Bagi Foerster, dalam Grandiosa (di unduh dari situs hubpages.com) karakter merupakan sesuatu yang mengualifikasi seorang pribadi. Karakter menjadi identitas yang mengatasi pengalaman kontingen yang selalu berubah. Dari kematangan karakter inilah, kualitas seorang pribadi diukur. Interaksi seseorang dengan orang lain menumbuhkan karakter masyarakat. Karakter adalah 'distinctive trait, distinctive quality, moral strength, the pattern of behavior found in an individual or group' (Peterson dan Seligman, 2004; Neufeld, 1991). Oleh karena itu, pengembangan karakter hanya dapat dilakukan melalui pengembangan karakter pribadi seseorang.

Dari beberapa pengertian di atas secara umum dapat dimaknai bahwa karakter merupakan nilai-nilai perilaku manusia yang baik yang berhubungan dengan Tuhan Yang Maha Esa, diri sendiri, sesama manusia, lingkungan, dan kebangsaan yang terwujud dalam pikiran, sikap, perasaan, perkataan, dan perbuatan berdasarkan norma-norma agama, hukum, tata krama, budaya, dan adat istiadat. Karenanya, karakter dikaitkan dengan sifat khas atau istimewa, atau kekuatan moral, atau pola tingkah laku seseorang.

Pembentukan karakter merupakan salah satu tujuan pendidikan nasional. Dalam Pasal 1 UU Sisdiknas tahun 2003 dinyatakan bahwa di antara tujuan pendidikan nasional adalah mengembangkan potensi peserta didik untuk memiliki kecerdasan, kepribadian dan akhlak mulia. Amanah peraturan perundang-undangan itu bermaksud agar pendidikan tidak hanya membentuk insan Indonesia yang cerdas, namun juga berkepribadian atau berkarakter, sehingga nantinya akan lahir generasi bangsa yang tumbuh berkembang dengan karakter yang bernafas nilainilai luhur bangsa serta agama. Pendidikan yang bertujuan melahirkan insan cerdas dan berkarakter kuat itu, juga pernah dikatakan Martin Luther King dalam Suyanto (di unduh dari situs mandikdasmen.depdiknas.go.id), yakni; intelligence plus character... that is the goal of true education (kecerdasan yang berkarakter yaitu tujuan akhir pendidikan yang sebenarnya).

Sementara itu, pendidikan adalah suatu usaha yang sadar dan sistematis dalam mengembangkan potensi peserta didik. Pendidikan adalah 
juga suatu usaha masyarakat dan bangsa dalam mempersiapkan generasi mudanya bagi keberlangsungan kehidupan masyarakat dan bangsa yang lebih baik di masa depan. Keberlangsungan itu ditandai oleh pewarisan budaya dan karakter yang telah dimiliki masyarakat dan bangsa. Oleh karena itu, pendidikan adalah proses pewarisan budaya dan karakter bangsa bagi generasi muda dan juga proses pengembangan karakter untuk peningkatan kualitas kehidupan masyarakat dan bangsa di masa mendatang. Dalam proses pendidikan karakter, secara aktif peserta didik mengembangkan potensi dirinya, melakukan proses internalisasi, dan penghayatan nilai-nilai menjadi kepribadian mereka dalam bergaul di masyarakat, mengembangkan kehidupan masyarakat yang lebih sejahtera, serta mengembangkan kehidupan bangsa yang bermartabat (Pusat Kurikulum, 2010b).

Dari pengertian tersebut dapat dimaknai pendidikan karakter adalah suatu sistem penanaman nilai-nilai karakter kepada peserta didik yang meliputi komponen pengetahuan, kesadaran atau kemauan, dan tindakan untuk melaksanakan nilai-nilai tersebut, baik terhadap Tuhan Yang Maha Esa, diri sendiri, sesama, lingkungan, maupun kebangsaan sehingga menjadi manusia insan kamil. Dalam arti lain, pendidikan karakter adalah segala sesuatu yang diusahakan pihak penyelenggara pendidikan yang dapat mempengaruhi serta membentuk karakter peserta didik melalui segala aktivitas pembelajaran. Lebih lanjut, Koesoema (2007) menyatakan bahwa pendidikan karakter memiliki peluang bagi penyempurnaan diri manusia.

Pendidikan karakter dilakukan melalui pendidikan nilai-nilai atau kebajikan yang menjadi nilai dasar karakter bangsa. Kebajikan yang menjadi atribut suatu karakter pada dasarnya adalah nilai. Oleh karena itu, pendidikan karakter pada dasarnya adalah pengembangan nilai-nilai yang berasal dari pandangan hidup atau ideologi bangsa Indonesia, agama, budaya, dan nilai-nilai yang terumuskan dalam tujuan pendidikan nasional (Pusat Kurikulum, 2010a). Pendidikan karakter juga mengajarkan kepada peserta didik tentang kemampuan dan kebiasaan bekerja keras serta selalu berupaya untuk melakukan yang terbaik dalam proses belajar mereka (Lickona, 2004).

Lickona (1992) dalam bukunya Educating for Character menyatakan bahwa"character education is the deliberate effort to help people understand, care about, and act upon core ethical values". Pendidikan karakter adalah usaha sengaja untuk membantu orang memahami, peduli, dan bertindak atas nilai-nilai etika inti. Lebih lanjut Lickona menyatakan bahwa "When we think about the kind of character we want for our children, it's clear that we want them to be able to judge what is right, care deeply about what is right, and then do what they believe to be right-even in the face of pressure from without and temptation from within". Esensi pendidikan karakter yaitu agar peserta didik bisa menilai apa yang benar, sangat peduli tentang apa yang benar, dan kemudian melakukan apa yang mereka yakini untuk menjadi benar, bahkan dalam menghadapi tekanan dari luar dan godaan dari dalam sekalipun.

Gagasan Lickona tersebut dapat dimaknai bahwa pendidikan karakter haruslah suatu proses perkembangan peserta didik dalam kegiatan pembelajaran yang melibatkan pengetahuan, perasaan, dan tindakan, dan dengan adanya ketersediaan landasan yang terpadu dengan struktur suatu upaya koheren dan komprehensif. Ini menggambarkan aktivitas peserta didik yang membuat mereka berpikir kritis dalam pertanyaan tentang moral dan etika, mengilhami mereka untuk menjadi berkomitmen pada tindakan moral dan etika, dan memberi mereka banyak kesempatan guna berlatih perilaku moral dan etika.

Pendidikan karakter menurut Suyanto (di unduh dari situs mandikdasmen.depdiknas.go.id) merupakan pendidikan budi pekerti atau akhlak mulia plus. Pengertian budi pekerti atau akhlak mulia lebih terkait dengan pilar-pilar sebagai berikut, yaitu cinta Tuhan dan segenap ciptaannya, hormat dan santun, dermawan, suka tolong menolong/kerja sama, baik dan rendah hati. Menurut Lickona (1992) pendidikan karakter senantiasa melibatkan aspek pengetahuan (cognitive), perasaan (feeling), dan tindakan (action). Tanpa ketiga aspek ini, maka pendidikan karakter tidak akan efektif. Dengan pendidikan karakter yang diterapkan secara sistematis dan berkelanjutan, seorang peserta didik akan 
menjadi cerdas emosinya. Kecerdasan emosi ini adalah bekal penting dalam mempersiapkan peserta didik menyongsong masa depan, karena seseorang akan lebih mudah dan berhasil menghadapi segala macam tantangan kehidupan, termasuk tantangan untuk berhasil secara akademis.

Hal ini sejalan dengan pendapatnya Peterson dan Seligman (2004), dalam buku 'Character Strength and Virtue', mengaitkan secara langsung 'character strength' dengan kebajikan. Character strength dipandang sebagai unsur-unsur psikologis yang membangun kebajikan (virtues). Salah satu kriteria utama dari 'character strength' adalah bahwa karakter tersebut berkontribusi besar dalam mewujudkan sepenuhnya potensi dan cita-cita seseorang dalam membangun kehidupan yang baik, yang bermanfaat bagi dirinya dan bagi orang lain. Oleh karena itu, menurut Buchori (2007), pendidikan karakter seharusnya membawa peserta didik ke pengenalan nilai secara kognitif, penghayatan nilai secara afektif, dan akhirnya ke pengamalan nilai secara nyata. Melalui pendidikan karakter diharapkan peserta didik mampu secara mandiri meningkatkan dan menggunakan pengetahuannya, mengkaji dan menginternalisasi serta mempersonalisasi nilai-nilai karakter dan akhlak mulia sehingga terwujud dalam pengamalan/ perilaku sehari-hari.

Pengamalan peserta didik secara nyata itu terbentuk karena adanya pendidikan sebagai proses internalisasi dari sekumpulan nilai karakter yang saling kait-mengkait dalam diri. Berkait dengan nilai karakter, banyak sekali ragamnya, masing-masing ahli memiliki pandangan dan argumen yang berbeda. Suyanto (di unduh dari situs mandikdasmen.depdiknas.go.id), misalnya, menyebut ada 9 pilar. Suparlan (di situs fisdk12.net) menyatakan bahwa pendidikan karakter meliputi 9 (sembilan) pilar, yaitu: 1) responsibility, 2) respect, 3) fairness, 4) courage, 5) honesty, 6) citizenship, 7) self-discipline, 8) caring, dan 9) perseverance. Sementara itu, character counts di Amerika (di situs charactercounts.org) mengidentifikasi nilai-nilai universal yang dianggap paling baik yang kemudian disebut enam pilar karakter (The Six Pillars of Character), yaitu: trustworthiness, respect, responsibility, fairness, caring, and citizenship. Pusat Kurikulum (2010b) menyatakan bahwa nilai-nilai yang dikembangkan dalam pendidikan karakter yang diidentifikasi dari sumber-sumber agama, pancasila, budaya, dan tujuan pendidikan nasional ada 18 nilai.

Dari beberapa pengertian tentang pendidikan karakter di atas, itulah sebabnya, definisi pendidikan karakter pun akan berbeda dengan jumlah dan jenis pilar karakter mana yang akan lebing menjadi penekanan. Sebagai contoh lagi (di unduh dari situs.ascd.org), disebutkan bahwa "character education involves teaching children about basic human values including honesty, kindness, generosity, courage, freedom, equality, and respect". Definisi pendidikan karakter ini lebih menekankan pentingnya tujuh pilar karakter. Dalam kaitannya dengan kebajikan, Peterson dan Seligman (2004) mengidentifikasikan sebanyak 24 jenis karakter.

Selanjutnya, dalam risalah ini, pendidikan karakter yang dikembangkan dalam model kurikulum rintisan merujuk pada Buku Pelatihan, Pusat Kurikulum (2010a) di mana pendidikan karakter memiliki esensi dan makna yang sama dengan pendidikan moral dan pendidikan akhlak. Tujuannya adalah membentuk pribadi peserta didik, supaya menjadi manusia yang baik, warga masyarakat, dan warga negara yang baik. Pendidikan karakter merupakan proses pendidikan untuk membentuk kepribadian peserta didik, yaitu pribadi yang bijaksana, terhormat, dan bertanggung jawab serta berakhlak mulia yang hasilnya terlihat dalam tindakan nyata. Dengan demikian, pendidikan karakter, secara implisit mengandung arti membangun sifat atau pola perilaku yang didasari atau berkaitan dengan dimensi moral yang positif atau yang baik, bukan yang negatif atau yang buruk.

Adapun kriteria peserta didik yang baik, seseorang yang baik, warga masyarakat yang baik, dan warga negara yang baik bagi suatu masyarakat atau bangsa, secara umum yakni dimilikinya nilai-nilai sosial tertentu, yang banyak dipengaruhi oleh budaya masyarakat dan bangsanya. Oleh karena itu, hakikat dari pendidikan karakter dalam konteks pengembangan model kurikulum ini adalah pedidikan nilai, yakni pendidikan nilai-nilai luhur yang bersumber dari agama, pancasila, budaya bangsa Indonesia 
sendiri, dan tujuan pendidikan nasional dalam rangka membina kepribadian generasi muda.

Pembentukan generasi muda melalui pembelajaran di satuan pendidikan rintisan senantiasa diajarkan secara sistematis dalam model pendidikan holistik yang memerlukan sebuah proses yang simultan dan berkesinambungan yang melibatkan seluruh aspek "knowing the good, feeling and loving the good, and acting the good" (di unduh dari situs karakterbangkit. blogspot.com). Knowing the good bisa mudah diajarkan sebab hanya bersifat pengetahuan saja. Setelah knowing the good harus ditumbuhkan feeling and loving the good, yakni bagaimana merasakan dan mencintai kebajikan menjadi engine yang bisa membuat peserta didik senantiasa mau berbuat sesuatu kebaikan. Pada Akhirnya tumbuh kesadaran bahwa, peserta didik mau melakukan perilaku kebajikan karena dia cinta dengan perilaku kebajikan itu. Setelah terbiasa mau berbuat kebajikan, maka acting the good itu berubah menjadi kebiasaan yang pada akhirnya akan membentuk kekuatan diri peserta didik.

Di samping itu, berdasarkan grand design yang dikembangkan Tim Pendidikan Karakter, Kemdiknas (2010), secara psikologis dan sosial kultural pembentukan karakter dalam diri peserta didik merupakan fungsi dari seluruh potensi individu manusia (kognitif, afektif, konatif, dan psikomotorik) dalam konteks interaksi sosial kultural (dalam keluarga, sekolah, dan masyarakat) dan berlangsung sepanjang hayat. Konfigurasi karakter dalam konteks totalitas proses psikologis dan sosial-kultural tersebut dapat dikelompokkan dalam: olah hati (spiritual and emotional development), olah pikir (intellectual development), olah raga dan kinestetik (physical and kinestetic development), dan olah rasa dan karsa (affective and creativity development).

Koesoema (2007) mengungkapkan secara singkat, bahwa pendidikan karakter diartikan sebagai sebuah bantuan sosial agar individu itu dapat bertumbuh dan menghayati kebebasannya dalam hidup bersama dengan orang lain. Pendidikan karakter, bertujuan membentuk setiap pribadi menjadi insan yang berkeutamaan. Pendidikan karakter di satuan pendidikan rintisan secara sederhana bisa didefinisikan sebagai, "pemahaman, perawatan, peningkatan, dan pelaksanaan keutamaan (practice of virtue). Oleh karena itu, pendidikan karakter di satuan pendidikan rintisan mengacu pada proses penanaman nilai berupa pemahamanpemahaman, tata cara merawat, menguatkan dan menghidupkan nilai-nilai itu, serta bagaimana peserta didik memiliki kesempatan untuk dapat melatihkan nilai-nilai tersebut secara nyata dalam kehidupan sehari-hari.

Mengembangkan pendidikan karakter di satuan pendidikan rintisan adalah lebih diutamakan pada bagaimana menanamkan nilainilai tertentu pada diri peserta didik. Nilai-nilai yang dimaksud, adalah yang berguna bagi pengembangan pribadinya sebagai makhluk individual sekaligus sebagai makhluk sosial dalam lingkungan satuan pendidikan dan masyaraktnya. Dan, pada intinya bentuk karakter apa pun yang dirumuskan tetap harus berlandaskan pada nilainilai universal. Oleh karena itu, satuan pendidikan yang mengembangkan nilai karakter adalah satuan pendidikan yang bisa membantu mengembangkan sikap, etika, moral dan tanggung jawab, memberikan kasih sayang kepada peserta didik dengan mengajarkan, menunjukkan, dan memberi keteladanan.

Dalam melaksanakan pendidikan karakter tersebut, semua komponen (stakeholders) satuan pendidikan rintisan dilibatkan, seperti tenaga pendidik, tenaga kependidikan, dinas pendidikan kabupaten/kota, dan masyarakat sekitar, termasuk komponen-komponen pendidikan itu sendiri, yaitu isi kurikulum, proses pembelajaran dan penilaian, kualitas hubungan, penanganan atau pengelolaan mata pelajaran, pengelolaan satuan pendidikan, pelaksanaan aktivitas atau kegiatan ko-kurikuler, pemberdayaan sarana prasarana, pembiayaan, dan ethos kerja seluruh warga dan lingkungan satuan pendidikan. Di samping itu, pembiasaan dan pembudayaan nilainilai karakter dalam segala aktivitas komunitas satuan pendidikan merupakan hal yang tidak bisa ditawar-tawar.

\section{Metodologi Pengembangan Model}

Studi tentang "Rintisan Pengembangan Pendidikan Karakter di Satuan Pendidikan" menggunakan metode penelitian pengembangan 
(design research) model. Di mana, komponen utama untuk menjelaskan metode ini ada tiga, yaitu: 1) model pengembangan, 2) prosedur pengembangan, dan 3) uji coba model (Tim Puslitjaknov, 2008). Model Pengembangan merupakan dasar untuk mengembangkan suatu produk/model yang akan dihasilkan. Model pengembangan yang dirujuk berupa model prosedural, yaitu suatu model yang bersifat deskriptif dengan mengikuti tahapan-tahapan yang harus diikuti guna menghasilkan sesuatu model.

Prosedur pengembangan merujuk pada pola prosedur pengembangan yang dilakukan Borg dan Gall (1983) dalam mengembangkan pembelajaran mini (mini course). Oleh karena itu, pengembangan model ini mengikuti tahapan-tahapan sebagai berikut: 1) sosialisasi kebijakan pengembangan model dan pelatihan, 2) pelaksanaan magang di satuan pendidikan pengalaman terpetik (best practice), 3) penyusunan kurikulum tingkat satuan pendidikan, dan 4) supervisi. Adapun satuan pendidikan rintisan dapat dianggap sebagai tempat uji coba model kurikulum pendidikan karakter. Tahapan pengembangan dianggap sebagai strategi pendekatan dalam pengembangan model, dan merupakan systems approach.

Pengembangan model dalam studi ini menggunakan konsep kekuatan karakter yang dikemukakan Peterson dan Seligman (2004), yang merupakan karakter baik yang mengarahkan peserta didik pada pencapaian keutamaan, atau trait positif yang terefleksi dalam pikiran, perasaan, dan tingkah laku (Park, Peterson, \& Seligman, 2004).

Studi ini bukanlah suatu studi penelitian kuantitatif yang dianalisis menggunakan statistik inferensial, tapi berbentuk kajian deskriptif dengan analisis wacana kritis. Prosedur studi ini berupa analisis hasil, pembahasan, generalisasi, dan penafsiran. Data dikumpulkan dengan menggunakan teknik dokumentasi (laporan hasilhasil kegiatan), fokus grup diskusi, dan terlibat peran dalam kegiatan.

Studi ini adalah deskriptif (descriptive research), di mana data utama diolah berdasarkan program kegiatan, pelaksanaan kegiatan, dan laporan hasil kegiatan di Pusat Kurikulum tahun
2010 yang berjudul "Implementasi kurikulum dan metode pembelajaran aktif berdasarkan nilai-nilai budaya bangsa untuk membentuk daya saing dan karakter bangsa" (Program Kerja Pusat Kurikulum, 2010c). Secara konseptual hasil studi akan mendeskripsikan fakta/kejadian yang terjadi pada saat itu Sax, 1979 dalam (Nana Sudjana \& Ibrahim 1989). Metode deskriptif juga merujuk pendapat Crowl (1996), menurutnya, deskriptif adalah menggambarkan dengan tujuan untuk dapat menerangkan dan memprediksi terhadap suatu gejala yang berlaku atas dasar data yang diperoleh di lapangan.

Teknik analisis data yang dipergunakan dalam studi ini merujuk pendapatnya Fairclough (1997), yaitu deskripsi, dan interpretasi. Pada deskripsi, dari data yang dikaji dari hasil-hasil kegiatan diuraikan secara sistematis, dan faktual mengenai fakta-fakta dan sifat secara apa adanya tanpa menghubungkan dengan aspek lain. Pada interpretasi, dianalisis hasil pada tahap deskripsi sekaligus dilakukan pembahasan dan dikemukakan penjelasannya. Fokus grup diskusi, dan amatan terlibat sekaligus juga bersifat informatif untuk pengayaan karena posisi penulis memungkinkan melakukan hal itu.

Lingkup kegiatan yang dikaji ini merupakan program rintisan penerapan model kurikulum di Pusat Kurikulum. Program tersebut pada tahun 2010 mulai diterapkan di 16 provinsi, di mana masing-masing provinsi ditetapkan 1 (satu) kabupaten/kota. Untuk masing-masing kabupaten/ kota ditetapkan rata-rata satu satuan pendidikan TK/PAUD, SD, SMP, SMA, SMK, SLB dan pendidikan nonformal (PKBM-khusus program kesetaraan). Data selengkapnya ada pada Tabel 1.

\section{Pembahasan Hasil Pengembangan Model}

Sebagaimana diungkap di atas bahwa terdapat empat tahapan yang dilakukan dalam mengembangkan model kurikulum pendidikan karakter sebagai rintisan. Karenanya, pada pembahasan hasil studi pengembangan ini, keempat tahapan tersebut dibahas satu persatu.

\section{Sosialisasi kebijakan pengembangan model dan pelatihan}

"Pendidikan untuk membangun karakter: mulai dari mana? ". Rancang awal, mulai dengan yang 
Tabel 1. Daftar Daerah dan Satuan Pendidikan Rintisan Tahun 2010 Pusat Kurikulum

\begin{tabular}{|l|l|l|c|}
\hline No & \multicolumn{1}{|c|}{ PROVINSI } & \multicolumn{1}{|c|}{ KABUPATEN / KOTA } & $\begin{array}{c}\text { JUMLAH } \\
\text { SATDIK }\end{array}$ \\
\hline 1. & NANGGROE ACEH DARUSSALAM & Kabupaten Bireun & 8 \\
\hline 2. & KEPULAUAN RIAU & Kota Tanjung Pinang & 8 \\
\hline 3. & SUMATERA BARAT & Kota Bukittinggi & 8 \\
\hline 4. & BANGKA BELITUNG & Kota Pangkal Pinang & 8 \\
\hline 5. & JAMBI & Kabupaten Muaro Jambi & 7 \\
\hline 6. & SUMATERA SELATAN & Kota Palembang & 8 \\
\hline 7. & JAWA BARAT & Kota Bandung & 8 \\
\hline 8. & JAWA TENGAH & Kota Semarang & 8 \\
\hline 9. & DI YOGYAKARTA & Kabupaten Bantul & 8 \\
\hline 10. & JAWA TIMUR & Kabupaten Sidoarjo & 8 \\
\hline 11. & NUSA TENGGARA BARAT & Kota Mataram & 8 \\
\hline 12. & KALIMANTAN TIMUR & Kota Balikpapan & 8 \\
\hline 13. & KALIMANTAN BARAT & Kota Singkawang & 8 \\
\hline 14. & SULAWESI UTARA & Kota Manado & 7 \\
\hline 15. & SULAWESI TENGAH & Kota Palu & 7 \\
\hline 16. & SULAWESI SELATAN & Kabupaten Gowa & 8 \\
\hline
\end{tabular}

paling dibutuhkan, dan yang paling dapat dilaksanakan. Itu suatu jawaban yang penulis siapkan. Dalam hal ini, penulis beranggapan bahwa pendidikan karakter tidak hanya untuk sebuah idealisme, namun hal ini juga hendaknya memiliki makna nyata dalam membangun kesejahteraan hidup komunitas satuan pendidikan dan sekaligus masyarakat. Sebab itu, pendidikan karakter pada tataran individu peserta didik dan tataran komunitas serta masyarakat luas perlu bersifat kontekstual. Oleh karena itu, sebagai langkah awal, forum sosialisasi dan pelatihan kepada seluruh pemangku kepentingan satuan pendidik-an rintisan di kabupaten/kota mutlak diperlukan agar mampu mengidentifikasi nilai karakter utama yang perlu dikuatkan terlebih dahulu yang bermanfaat bagi komunitas yang bersangkutan.

Menurut hemat penulis, kegiatan sosialisasi dan pelatihan program pengembangan model kurikulum pendidikan karakter pada satuan pendidikan rintisan merupakan suatu tantangan tersendiri bagi Pusat Kurikulum. Pada, satu sisi, di sanalah bersandar harapan agar semua pemangku kepentingan pendidikan yang berkait dengan satuan pendidikan rintisan memahami, menyadari dan memiliki komitmen untuk mengimplementasikannya. Di sisi lain, pendidikan karakter merupakan kebijakan pemerintah yang harus terus didorong pengimplementasiannya.
Sebab hakikat dari pendidikan itu sendiri sebenarnya adalah untuk membangun karakter (character building) peserta didik.

Sebagai kebijakan pemerintah, biasanya lapangan belum memahami secara cepat. Atas dasar itu, maka pelaksanaan program sosialisasi dan pelatihan terhadap pemangku kepentingan di satuan pendidikan rintisan mulai dari perencanaan, pengelolaan, implementasi, dan pengawasan perlu dilakukan dengan kehatihatian dan dikoordinasikan dengan berbagai pihak secara cermat. Banyak sekali pertanyaan yang harus dijawab manakala menggulirkan program ini. Misalnya, apa itu pendidikan karakter berbasis budaya sekolah, dan budaya kelas? Bagaimana setiap individu yang terlibat dalam satuan pendidikan dapat berperan serta secara aktif dalam pembentukan budaya sekolah, budaya kelas yang berjiwa pendidikan karakter? Bagaimana budaya sekolah, dan budaya kelas itu terbentuk dan bagaimana menjaga keberlangsungannya sehingga sekolah memiliki sebuah tradisi pendidikan yang kokoh? Bagaimana sekolah mendesain pendidikan karakter berbasis budaya sekolah, dan budaya kelas? yang tidak kalah penting adalah seperti apa wujud kurikulum satuan pendidikan yang bermuatan pendidikan karakter itu?.

Dari amatan penulis dalam pelaksanaan kegiatan dan dari laporan hasil kegiatan dapat 
disintesiskan bahwa kegiatan sosialisasi dan pelatihan merujuk pendapatnya Macionis (1997), yaitu adanya pengalaman sosial seseorang dalam kurun waktu tertentu yang memungkinkan seseorang tersebut mengembangkan potensi guna mempelajari pola-pola kebudayaan. Artinya, sosialisasi dan pelatihan dimaknai sebagai sebuah proses mengkomunikasikan gagasan dan peningkatan kapasitas kepada komunitas satuan pendidikan rintisan implementasi pengembangan model kurikulum pendidikan karakter secara komprehensif. Hal ini sesuai dengan tujuan utama dari sosialisasi, yaitu untuk menyamakan persepsi kepada seluruh satuan pendidikan rintisan berkaitan dengan substansi, program rintisan beserta tahapannya. Dengan kegiatan ini diharapkan seluruh pemangku kepentingan di daerah sadar, komitmen, dan termotivasi untuk melaksanakan kegiatan tersebut secara sungguh-sungguh.

Esensi dari program sosialisasi dan pelatihan adalah dalam upaya peningkatan revitalisasi pendidikan karakter di satuan pendidikan. Metode penyampaian, bahan pelatihan (materi), cara menjelaskan materi selalu berkait dengan mata pelajaran, pengembangan diri, muatan lokal, pembiasaan, dan pembudayaan yang kesemuanya dihubungkan dengan pendidikan karakter. Materi ini dikemas dengan pendekatan cara belajar aktif di mana peran trainer/fasilitator/staf teknis Pusat Kurikulum, dan trainee/pendidik dan tenaga kependidikan kabupaten/kota bersifat dialogis dan sejajar. Temuan tersebut diperkuat dari hasil grup diskusi secara terfokus dengan trainer/fasilitator pada pertemuan rutin setiap hari Senin, yang mengemuka bahwa mereka umumnya mampu mendorong trainee lebih aktif dalam pelatihan dan lebih intens berdialog untuk membahas dan mendiskusikan materi-materi beserta pokok permasalahannya yang diberikan dalam setiap sesi. Trainee dalam hal ini terdiri dari unsur kepala sekolah, wakil kepala sekolah bidang kurikulum, guru, pengawas, dan staf serta pejabat dari dinas pendidikan kabupaten/kota yang umumnya diisi oleh kepala seksi kurikulum.

Dalam buku panduan sosialisasi-di mana kegiatan tersebut efektif dilakukan selama 4 haridinyatakan bahwa terdapat empat strategi yang ditempuh. Pertama, diawali dengan paparan tentang kebijakan nasional, apa-mengapa-dan bagimana program satuan pendidikan rintisan dan juga konsep-konsep yang berkenaan dengan pendidikan karakter. Kedua, workshop dan diskusi dilakukan untuk mengembangkan KTSP satuan pendidikan rintisan (dalam hal ini bersifat simulasi). Ketiga, kunjungan ke setiap satuan pendidikan rintisan guna menemukan data awal tentang situasi dan kondisi satuan pendidikan yang akan dijadikan sebagai bahan analisis konteks. Dalam kunjungan ini sekaligus didokumentasikan kondisi awal satuan pendidikan rintisan yang dapat berwujud: dokumen KTSP, rencana kerja satuan pendidikan (RKS), rencana kegiatan dan anggaran satuan pendidikan (RKAS), foto-foto yang menggambarkan beraneka ragam situasi dan kondisi satuan pendidikan.

Foto-foto yang memuat situasi dan kondisi awal satuan pendidikan, dan kondisi akhir satuan pendidikan dianggap penting karena ia bisa mengungkap cerita dan fakta apa adanya. Misalnya foto tentang kebersihan satuan pendidikan, keberadaan sampah, taman, kantin, ruang belajar, kondisi laboratorium, kamar mandi/WC, sanitasi/ saluran air kotor, tempat pembuangan sampah, pengolahan sampah, tempat ibadah, kebiasaankebiasaan, dan infrastruktur lainnya. Dengan rekaman berupa foto, trainer/fasilitator berusaha sekuat tenaga untuk menggali realita di kondisi awal maupun di kondisi akhir. Memotret situasi dan kondisi awal maupun kondisi akhir (pada akhir tahun anggaran 2010) satuan pendidikan dari berbagai sisi demi menjelaskan "profil" satuan pendidikan apa adanya bisa secara pasti memersepsikan "sosok" satuan pendidikan secara proporsional. Memindai satuan pendidikan dengan cara memotretnya, paling tidak bisa menjelaskan tentang seperti apa satuan pendidikan yang sesungguhnya. Apalagi ditambah keterangan dalam laporan trainer/fasilitator, bisa memberi perspektif yang mendekati kebenaran yang pada gilirannya akan membantu memudahkan pengembang model (trainer/fasilitator) menyimpulkan tingkat keberhasilan maupun ketidakberhasilan dari suatu program model satuan pendidikan rintisan.

Keempat, di sesi akhir kegiatan sosialisasi dan pelatihan didiskusikan berbagai hal yang diperoleh dari data awal, kemudian satuan 
pendidikan diminta untuk memikirkan, membuat program tindak lanjut, dan sekaligus akan menetapkan apa saja yang perlu dilakukan pada tahapan selanjutnya, misalnya membuat rencana aksi satuan pendidikan. Pada sesi ini, sekaligus juga diadakan penanda tanganan naskah komitmen bersama antara kepala satuan pendidikan rintisan, kepala dinas pendidikan kabupaten/kota, dan kepala Pusat Kurikulum. Tiga dari empat strategi pertemuan tersebut umumnya diadakan secara klasikal. Tempat pertemuan biasanya di ruang sidang dinas pendidikan kabupaten/kota setempat atau di salah satu ruangan sebuah satuan pendidikan setempat, misalnya SMA atau SMK.

Hasil kajian dari laporan kegiatan sosialisasi ditemukan bahwa hal-hal seperti diungkap berikut ini merupakan substansi yang esensi disampaikan di awal pada saat sosialisasi program kepada seluruh satuan pendidikan rintisan. Di samping itu, materi tentang kebijakan pemerintah, konsepsi tentang pendidikan karakter, bagaimana mengintegrasikan nilai ke dalam mata pelajaran, bagaimana membangun budaya kelas dan sekolah, perilaku apa yang harus diteladankan oleh seluruh komunitas satuan pendidikan, dan bagaimana proses internalisasi nilai-nilai karakter oleh peserta didik difasilitasi merupakan sesi-sesi pencerahan yang mendapat penekanan.

Bahwa penerapan pendidikan karakter di satuan pendidikan rintisan bila tidak didesain secara baik bisa jadi malah terkesan seperti tempel-tempel (meminjam istilah Romo Baskoro pada kegiatan TOT karakter Pusat Kurikulum tanggal 24 sd 27 Agustus 2010 di Hotel Mercure, Ancol, Jakarta), gimmick, nggak ada soul, bagus di wacananya tetapi kosong dalam realitanya, kurang bermakna, tidak ada esensinya, dan malah terkesan untuk kebutuhan sesaat, sehingga perilaku komunitas satuan pendidikan nampak semu. Dengan demikian, hal tersebut akan menggambarkan kurangnya "karakter" para pengelolanya. Karenanya, desain pendidikan karakter di satuan pendidikan rintisan harus jelas, tegas, tertulis, dan melibatkan seluruh komunitas satuan pendidikan (dan bila perlu pemda terlibat, DPRD terlibat, dan juga orangtua peserta didik bersama-sama dengan komite sekolah).

Hasil diskusi secara terfokus dengan staf dalam pertemuan rutin setiap hari Senin mengemuka bahwa penerapan pendidikan karakter pada satuan pendidikan rintisan dapat dimaknai sebagai upaya pembentukan/ penanaman nilai-nilai yang pada dasarnya memiliki dua karakteristik, yaitu yang bisa diraba (tangibel) seperti kebersihan dan sopan santun maupun yang tidak bisa diraba (intangibel), seperti ide dan gagasan. Oleh karena itu, dalam konteks pembentukan karakter komunitas satuan pendidikan rintisan yang merupakan miniatur masyarakat, posisi visi dan misi sangat penting. Visi bukan sekadar kalimat, tetapi juga harus bisa mengandung karakter, tampilan/gaya, belief, ideologi, dan cita-cita yang mempunyai visi. Dalam konsep "pemasaran" satuan pendidikan yang bersangkutan kepada khalayak luas, visi juga dapat berfungsi sebagai tanda pengenal agar supaya masyarakat luas tahu seperti apa satuan pendidikan tersebut (school branding).

Berkait dengan itu, Kepala Pusat Kurikulum di awal program telah menggulirkan "kebijakan" agar satuan pendidikan rintisan sebaiknya didorong untuk memulai dengan nilai-nilai karakter yang sederhana dulu, yang tangibel, dan yang mudah dilaksanakan seperti bersih, rapi, nyaman, aman, disiplin, salam, sapa, ramah, murah senyum, sopan santun, dan religiusitas. Rasionalitas dari itu, menurut hemat penulis dilandasi beberapa hal: 1) ada hal yang mendasar bagi kehidupan sosial manusia yang bersifat universal, yaitu bahwa semua orang pada dasarnya suka kebersihan, suka kenyamanan, suka dihargai, suka keteraturan, suka keramahan, dan beragama (sehingga ada ungkapan bagaimana nilai-nilai karakter lain akan tumbuh baik kalau sekolahnya saja jorok dan kotor, anaknya saja tidak sopan, tidak ramah, tidak disiplin), 2) satuan pendidikan dianggap sebagai "pemain-pemain utama" dalam mengembangkan pribadi-pribadi terdidik yang perlu memahami pengertian tentang keutamaan-keutamaan, keindahan, dan ketidaksempurnaan-kesempurnaan, dan 3) dalam Islam akhlak Laa Ilaaha Illallaah sebagai kumpulan nilai kebenaran, kebaikan, dan keindahan yang membentuk akhlak dan karakternya.

Hasil kegiatan sosialisasi dan pelatihan penyusunan KTSP yang bermuatan nilai pendidikan karakter kepada trainee yang diramu 
dari amatan terlibat, diskusi grup secara terfokus, laporan kegiatan, dan komunikasi langsung dengan komunitas satuan pendidikan dapat disimpulkan beberapa hal. Pertama, bahwa wacana pendidikan karakter memang menarik dibicarakan. Menarik bukan karena dianggap sesuatu yang baru, tetapi lebih karena hal sepenting ini, pembentukan karakter yang menyangkut pertumbuhan individu dan warga negara di masa kini dan mendatang mestinya tidak hanya dibicarakan oleh sekelompok orang dalam forum ini. Diskursus terbuka dengan melibatkan seluruh komponen masyarakat mestinya merupakan keniscayaan. Menurut trainee karena keberhasilan pendidikan karakter adalah tanggung jawab semua.

Kedua, trainee umumnya memahami bahwa saat ini pendidikan karakter dirasakan amat mendesak. Bahkan, sebagian trainee ada yang menganggap agak terlambat. Pendidikan karakter menurut trainee merupakan sebuah konsep yang bagus, indah, jelas, dan mudah dipahami, yaitu yang berkaitan dengan pengembangan pembentukan diri individu secara utuh, serta dampak-dampak pembentukan karakter bagi kelangsungan sebuah masyarakat. Namun, dari amatan terlibat terungkap pula rasa kekhawatiran trainee, jangan-jangan program pemerintah yang bagus ini nantinya mengalami nasib yang sama seperti para pendahulunya, misalnya tentang life skill, muatan lokal, belajar aktif, sekolah pembangunan dan lainnya. Bagus di awal dan berujung menjadi tidak jelas, dan tidak tepat sasaran, justru malah bersifat kontraproduktif bagi pembentukan karakter itu sendiri. Hanya menjadi knowing semata.

Ketiga, trainee umumnya memahami bahwa pendidikan karakter yang berpusat pada pembelajaran mengutamakan isi nilai-nilai tertentu yang harus dipelajari, serta sekumpulan kualitas keutamaan moral, seperti kebersihan, sopan santun, beribadah, kerapihan, kenyamanan, kemurahan hati dan senyum, dan lain-lain, agar diketahui dan dipahami oleh peserta didik. Klarifikasi nilai ini lebih mengutamakan proses penalaran moral serta pemilihan nilai yang mesti dimiliki oleh peserta didik. Fokus pembelajarannya mengutamakan pengetahuan, pengertian, dan pemahaman. Pada pertumbuhan karakter moral, akhlak dan kepribadian lebih mengutamakan perilaku yang merefleksikan penerimaan nilai-nilai yang diyakini serta menekankan unsur motivasi, serta aspek-aspek kepribadian yang relatif stabil yang akan mengarahkan tindakan individu peserta didik. Fokus ini dalam pembelajaran lebih meng-utamakan perilaku, kebiasaan, keteladanan, dan pembudayaan dengan keajegan dan konsisten.

Keempat, umumnya trainee satu sisi memahami bahwa nilai-nilai pendidikan karakter bisa dilakukan melalui berbagai macam cara seperti terintegrasi melalui mata pelajaran muatan lokal; terintegrasi melalui pembelajaran setiap mata pelajaran; melalui program pengembangan diri yang dapat berupa kegiatan ekstrakurikuler, pembiasaan, kegiatan rutin, kegiatan spontan, kegiatan terprogram, bazar sekolah, out bond, kantin kejujuran maupun yang terintegrasi dengan kegiatan-kegiatan lain yang mempergunakan ruang-ruang pembelajaran yang tersedia dalam keseluruhan dinamika pendidikan di satuan pendidikan. Di sisi lain, trainee umumnya juga memahami bahwa apapapun metodologi yang dipilih, setiap pendekatan penanaman nilai-nilai pendidikan karakter akan memiliki konsekuensi berkaitan dengan kesiapan tenaga guru, prioritas nilai, kesamaan visi, misi antara anggota komunitas satuan pendidikan tentang pendidikan karakter, struktur dan sistem pembelajaran, kebijakan kepala satuan pendidikan, sarana dan prasarana yang tersedia, kebijakan keberpihakan dinas pendidikan kabupaten/kota, dan juga kebijakan keberpihakan pemerintah daerah setempat. Di samping itu, wujud cita-cita bersama yang terpantul lewat visi, misi, dan rencana kegiatan sekolah yang terangkum dalam KTSP juga menggambarkan akan seperti apa satuan pendidikan dalam menindaklanjutinya.

\section{Magang di satuan pendidikan yang memiliki pengalaman terpetik (best practice)}

Berdasarkan keterlibatan penulis selama ini dalam mengikuti berbagai pertemuan untuk membahas pendidikan karakter dapat disimpulkan bahwa pada hakikatnya setiap satuan pendidikan mempunyai prioritas nilai-nilai pendidikan karakter yang diterapkannya yang berbeda antara satuan pendidikan yang satu dengan satuan pendidikan 
yang lain. Walaupun demikian, terdapat beberapa ciri-ciri dan aspek yang hampir sama yang dapat dijumpai pada setiap nilai-nilai pendidikan karakter yang diwujudkannya seperti pembiasaan, amalan agama, kebersamaan, saling menghormati, saling mencintai dan saling menolong antarsesama, sistem kekeluargaan atau kekerabatan, berkesenian, sistem pengetahuan, serta keteladanan. Hal-hal semcam itu dapat disebut pula sebagai pola penerapan nilai pendidikan karakter sejagat (universal pattern of character education). Karenanya, pengalaman dari setiap satuan pendidikan seperti itu bisa dijadikan rujukan untuk belajar atau magang bagi trainee.

Hasil dari grup diskusi secara terfokus dengan trainer/fasilitator mengemuka bahwa kegiatan magang membawa pengertian pada segala hasil dan ide tentang nilai pendidikan karakter yang dipelajari dari satuan pendidikan di tempat magang sebagai rujukan atau resep untuk diterapkan ke tempat asalnya. Apalagi ditambah hasil laporan magang oleh trainee, yang mendeskripsikan bahwa segalanya dipelajari, termasuklah segala kepercayaan, nilai-nilai universal, adat istiadat, hukum, moral, institusi sosial, seni yang ada dan terjadi di tempat magang. Dalam pengertian ini, maka ditekankan bahwa hakikat magang itu mesti mempelajari dan mengalami. Bagi trainee sebagai peserta, dalam konteks magang, pemikiran proses pembelajaran mesti dijadikan tumpuan utama dalam konsepsinya mengenai pembiasaan dan perilaku untuk hidup bersama dalam komunitas satuan pendidikan, sebagai satu keseluruhan cara hidup manusia, yang meliputi hasil-hasil kehidupan kelompok yang bercorak bisa diraba (tangibel) seperti kebersihan, dan sopan santun maupun yang tidak bisa diraba (intangibel), seperti ide dan gagasan.

Dari sisi satuan pendidikan rintisan, program magang yang berlandaskan pada realitas satuan pendidikan sebagai best practises dalam implementasi nilai-nilai pendidikan karakter yang majemuk dan unik menjadi penting agar diperoleh pengalaman sebagai panduan "kehidupan" bagi satuan pendidikan peserta magang yang bersangkutan. Hal ini mengemuka dalam amatan terlibat. Begitu pula bagi satuan pendidikan yang memiliki pengalaman terpetik (best practises) yang menjadi rujukan terselenggaranya nilai-nilai pendidikan karakter jelas harus dapat mengantarkan atau pun mendampingi trainee sebagai peserta program magang pada kemandirian, kedewasaan, kecerdasan serta yang committed untuk menjadi pendidik dan tenaga kependidikan dalam menerapkan nilai pendidikan karakter secara konsekuen dan konsisten di satuan pendidikannya.

Penggalian pengetahuan dan pengalaman secara langsung sebagai wahana bagi pembentukan pola pikir (mindset) dan sikap mental pendidik dan tenaga kependidikan dalam merancang dan menerapkan nilai-nilai pendidikan karakter di masing-masing satuan pendidikan merupakan tugas yang amat penting dan perlu bagi satuan pendidikan rintisan. Hal ini mengemuka dari hasil grup diskusi secara terfokus dengan trainer/fasilitator. Singkatnya, program magang adalah sarana untuk memberikan jawaban atas pertanyaan: "Siapa kita, atau apa identitas kita? Akan kita jadikan seperti apa satuan pendidikan kita? Watak atau perilaku atau nilai-nilai pendidikan karakter macam apa yang kita inginkan? Bagaimana kita harus mewujudkan implementasinya di satuan pendidikan kita?", dan masih banyak lagi pertanyaan lainnya.

Melihat realitas pengertian magang seperti itu, jelas menunjukkan bahwa proses magang itu dinamik, pada dasarnya melihat dan merasakan sebagai satu proses, yaitu suatu usaha dan upaya dari trainee sebagai peserta program magang untuk menjawab pelbagai tantangan terhadap apa dan bagaimana nilai-nilai pendidikan karakter dilaksanakan pada suatu satuan pendidikan. Untuk menghadapi tantangan, trainee sebagai peserta program magang mencurahkan segala kemampuannya dalam merekam informasi dan menghayati pelaksanaannya. Proses yang dapat mengawal situasi seperti itu dalam program magang hanyalah dapat dicapai melalui pelibatan secara baik, baik dalam lingkup pembelajaran, pembiasaan keteladanan maupun pembudayaan sekolah.

Hasil dari pengkajian laporan-laporan magang dapat ditarik kesimpulan lain bahwa dalam melaksanakan kegiatan magang, trainee sebagai peserta menyatakan program magang merupakan proses yang tidak pernah selesai, 
karena tantangan di tempat magang setiap saat selalu muncul untuk dihadapi. Apalagi bila mengingat waktu yang disediakan untuk magang hanya satu minggu. Padahal program magang merupakan usaha untuk menyatakan tentang kewujudan keterlaksanaan nilai-nilai pendidikan karakter di dalam masyarakat satuan pendidikan. Satuan pendidikan menurut trainee, dapat dimaknai sebagai "lapangan eksistensi". Untuk itu, bagi satuan pendidikan yang memiliki pengalaman terpetik (best practises) haruslah dibaca dan dipahami di dalam konteks nilai-nilai pendidikan karakter pula. Perwujudan penanaman nilai-nilai pendidikan karakter, dapat dibaca dari pemikiran /ide/gagasan dan aktivitas seluruh komunitas satuan pendidikan best practises yang diwujudkan dalam eksistensinya sebagai proses humanization atau menjadikan manusia itu manusia.

Dari bahasan di atas dapat disimpulkan bahwa program magang adalah proses aktif dan inisiatif yang muncul dari satuan pendidikan rintisan pelaksana nilai-nilai pendidikan karakter. Hal itu hanya akan bisa terwujud sebagai suatu kegiatan nyata apabila terpenuhi oleh tiga faktor pendukungnya, yaitu: 1) adanya kemauan, 2) adanya kemampuan, dan 3) adanya kesempatan untuk berpartisipasi. Kemauan dan kemampuan berpartisipasi lebih berasal dari satuan pendidikan belajar yang dalam hal ini dimaksudkan sebagai satuan pendidikan rintisan. Kesempatan berpartisipasi aktif mesti datang dari pihak luar yang memberi kesempatan, yang dimaksud ini adalah pihak Pusat Kurikulum, Badan Litbang, Kemendiknas.

Dari hasil-hasil laporan magang dapat sekaligus juga di tarik simpulan lain ditinjau dari sisi pengalaman trainee. Beragam kisah bisa dikumpulkan dari peristiwa magang. Di sana banyak pengalaman unik bagi trainee "berjuang" untuk mendatangi tempat magang. Satu di antaranya terungkap bahwa siapa nyana, ia akan bisa menginjakkan kaki ke Jakarta. Menurut mereka selama ini Jakarta hanya diketahui lewat koran, buku, dan media televisi. Hal-ihwal kehidupan Jakarta bagi yang telah ke sana dalam konteks sosial bukanlah sesuatu yang baru. Tetapi jika ia kemudian melibatkan seseorang yang sepanjang hidupnya belum pernah ke ibu kota negara, pastilah menjadi sesuatu yang seru.

\section{Penyusunan KTSP}

Dalam pertemuaan koordinasi awal antara Pusat Kurikulum dengan 16 kepala dinas pendidikan kabupaten/kota daerah rintisan pada tanggal 21 sd 24 Juli 2010 di Hotel Horison, Bandung ditekankan bahwa masing-masing satuan pendidikan rintisan diberi kesempatan seluasluasnya yang harus digunakan untuk menanamkan nilai-nilai pendidikan karakter secara inovatif dan kreatif, dan menerapkannya dalam praktik belajar mengajar sehari-hari yang dapat mendukung perubahan sosial dalam masyarakat satuan pendidikan secara luas. Esensi kesepahaman ini sejatinya adalah satuan pendidikan memiliki keleluasaan untuk menyusun kurikulumnya sendiri yang disesuaikan dengan kebutuhan, potensi, dan kondisi daerah maupun satuan pendidikan termasuk dengan muatan nilainilai pendidikan karakter.

Kebijakan nasional tersebut selaras dengan amanat Pasal 36 Ayat (2) Undang-Undang Nomor 20 Tahun 2003 tentang Sistem Pendidikan Nasional yang menyatakan bahwa kurikulum pada semua jenjang dan jenis pendidikan dikembangkan dengan prinsip diversifikasi sesuai dengan satuan pendidikan, potensi daerah, dan peserta didik. Konfigurasi pengembangan kurikulum seperti itu merupakan kebijakan nasional dalam memasuki era perubahan paradigma penyelenggaraan pendidikan yang semula sentralisasi ke desentralisasi. Semula kurikulum dikembangkan oleh Pusat Kurikulum, sekarang langsung disusun oleh masing-masing satuan pendidikan.

Dengan adanya kebijakan yang baru maka otomatis akan mendorong terjadinya perubahan pola pikir, dan perubahan cara kerja bagi pengelola satuan pendidikan. Dulu, mereka terbiasa dengan melaksanakan kurikulum, sekarang dituntut harus mampu melakukan penyusunan KTSP. Yang lebih penting lagi, yakni mereka dituntut harus mampu melakukan pengembangan kurikulum secara terus menerus sesuai siklus pengembangan kurikulum, yaitu penyusunan, pelaksanaan, dan evaluasi. Di mana, kurikulum merupakan seperangkat rencana dan pengaturan mengenai tujuan, isi, dan bahan pelajaran serta cara yang digunakan sebagai pedoman penyelenggaraan kegiatan pembelajaran untuk mencapai tujuan pendidikan 
tertentu (UUSPN Pasal 1 Butir 19).

Dalam menyikapi tantangan dan harapan tersebut nampaknya tidak berbanding lurus dengan realitas yang terungkap di lapangan. Sutjipto (2009) dalam kajiannya menyimpulkan bahwa satuan pendidikan umumnya belum siap mengembangkan dan menyusun KTSP secara mandiri. KTSP yang telah dihasilkan umumnya baru menyentuh tataran dokumen hasil rekayasa dari copy paste file-file elektronik KTSP sekolah lain yang beredar. KTSP yang merupakan kurikulum operasional yang mestinya menjadi tolok ukur pencapaian visi, misi dan tujuan sekolah belum terepresentasi secara jelas dan tegas dalam dokumen. KTSP hanya berfungsi dan dimaknai sebagai dokumen semata. Temuan ini sejalan dengan data yang terungkap dari laporan kegiatan sosialisasi bahwa satuan pendidikan rintisan umumnya belum memahami bagaimana cara menyusun nilai-nilai pendidikan karakter secara terintegrasi ke dalam KTSP.

Atas dasar berbagai permasalahan penyusunan KTSP oleh satuan pendidikan rintisan seperti di atas, maka dalam grup diskusi secara terfokus dengan trainer/fasilitator mengemuka bahwa penyusunan KTSP kepada satuan pendidikan rintisan haruslah memperoleh pendampingan secara langsung dari Pusat Kurikulum secara baik. Hal itu tentunya tidak akan mengurangi makna bahwa satuan pendidikan bisa bebas menyusun kurikulum sendiri agar relevansi pendidikan antara nasional dengan kebutuhan pengembangan masyarakat di sekitar terus terjaga.

Di samping itu, menurut trainer/fasilitator dengan pola bimbingan dan pendampingan yang intens pada satuan pendidikan rintisan akan mampu mengembangkan kurikulum dalam arti yang luas, yaitu kurikulum sebagai produk, kurikulum sebagai program, kurikulum sebagai hasil belajar yang diinginkan, dan kurikulum sebagai pengalaman belajar bagi peserta didik. Dengan demikian, konteks pengimplementasian school based management oleh satuan pendidikan rintisan dapat didorong lebih baik. Pada gilirannya satuan pendidikan rintisan akan memiliki prakarsa, inisiatif, dan kemandirian serta berani membuat perubahan yang diperlukan.

Demikian pula menurut trainee, berdasarkan amatan terlibat, peran kepala satuan pendidikan yang mampu membangkitkan prakarsa, motivasi komunitas satuan pendidikan, menciptakan iklim organisasi yang kondusif sehingga pada gilirannya dapat mengembangkan KTSP secara kontekstual dan kultural di masing-masing satuan pendidikan yang disesuaikan dengan situasi dan kondisi, karakteristik, kebutuhan, dan lingkungan amat diperlukan. Oleh karena itu, dalam penyusunan KTSP (penulis cenderung memakai istilah penyempurnaan KTSP sebab umumnya satuan pendidikan telah mempunyai perangkat kurikulum tersebut) kepala satuan pendidikan umumnya selalu aktif mengikuti kegiatan sejak hari pertama hingga terakhir.

Menurut trainer/fasilitator strategi yang ditempuh dalam penyusunan KTSP pada satuan pendidikan rintisan umumnya diawali dengan melakukan analisis konteks terhadap: kurikulum yang sudah ada/dilaksanakan, kondisi peserta didik, guru, sarana dan prasarana, lingkungan satuan pendidikan, potensi lingkungan sekitar, dan hal-hal lain yang dianggap berpengaruh signifikan terhadap proses belajar-mengajar. Tahap berikutnya, masing-masing satuan pendidikan rintisan menentukan nilai-nilai pendidikan karakter apa yang dianggap paling sesuai berdasarkan hasil analisis konteks.

Nilai-nilai karakter yang diprioritaskan ini merupakan hasil dari penelusuran kembali oleh semua pemangku kepentingan satuan pendidikan di mana setiap gerak, kegiatan, pemikiran, diskusi, praksis yang terjadi di satuan pendidikan, direnungkan, dan dievaluasi, sehingga jalan perbaikan ke depan terbuka. Menurut penulis, inilah salah satu sikap yang dimiliki oleh satuan pendidikan rintisan manakala mereka akan mengembangkan pendidikan karakter yang berkesinambungan. Hal ini mengemuka pada saat pertemuan kegiatan sosialisasi.

Berdasarkan hasil dari grup diskusi secara terfokus dengan trainer/fasilitator mengemuka bahwa pada saat melakukan pendampingan menyusun KTSP, makna mendesain/perancangan nilai karakter seperti apa menjadi penekanan advokasi. Artinya, nilai-nilai karakter itu akan ditanamkan melalui apa saja, harus jelas. Misalnya, bagaimana visi, misinya, bagaimana sosial kultural masyarakat sekitar, pembiasaan 
seperti apa yang disepakati, terintegrasi dengan mata pelajaran apa saja, kegiatan apa saja yang dijadikan spontan rutin dan terus menerus. Kegiatan ekstrakurikuler yang mana saja yang bisa dijadikan ajang penanaman nilai-nilai yang dimaksud. Juga, termasuk bagaimana mewadahi dalam rencana kerja, dan rencana kegiatan anggaran sekolah (RKS/RKAS).

Workshop menurut trainer/fasilitator menjadi dasar bekerja dalam menyusun KTSP. Kemudian diiringi dengan diskusi secara intensif dalam menyelesaikan problematika pengintegrasian nilai karakter ke dalam komponen KTSP. Selanjutnya, presentasi hasil workshop untuk memperoleh masukan guna perbaikan menjadi ajang pergumulan yang tidak kalah seru. Dengan pola demikian akan berkelindan antara nilai-nilai karakter yang dikembangkan dalam pendidikan tersebut dengan kurikulum satuan pendidikan yang bertujuan mengembangkan secara berkesinambungan dan sistematis karakter peserta didik.

Kegiatan penyusunan KTSP ini juga melibatkan pengawas satuan pendidikan, tim pengembang kurikulum provinsi, tim pengembang kurikulum kabupaten/kota, dan tentu saja guru-guru sebagai leading sectornya. Waktu yang dipergunakan dalam kegiatan penyusunan umumnya selama 5 hari efektif. Kerangka KTSP umumnya sesuai dengan "standar" yang telah "terbakukan", seperti tampak pada Tabel 2 berikut ini.
Hasil dari pengkajian laporan-laporan penyusunan dan pengkajian dokumen KTSP dapat disimpulkan bahwa penanaman pendidikan karakter yang terefleksikan ke dalam KTSP pada dasarnya mencakup pengembangan substansi, proses dan suasana atau lingkungan yang menggugah, mendorong dan memudahkan peserta didik untuk mengembangkan kebiasaan baik di kelas, satuan pendidikan maupun dalam kehidupan sehari-hari. Misalnya senang kebersihan, kerapihan, sopan santun, ramah, murah senyum, aman, nyaman, indah, sejuk, disiplin, beribadah keagamaan dan lain-lain. Dalam arti bahwa dokumen KTSP yang dikembangkan telah bermuatan nilai-nilai karakter yang umumnya dirancang berbasis kelas (terintegrasi dalam mata pelajaran), berbasis kultur sekolah (terintegrasi dalam pengembangan diri), dan berbasis komunitas (melalui pembiasaan dan pembudayaan).

Desain yang dikembangkan dalam KTSP tersebut menurut trainee diharapkan dapat diimplementasikan dengan sungguh-sungguh sehingga tumbuh dan berkembang menjadi budaya satuan pendidikan dengan didasari oleh kesadaran, keyakinan, kepekaan dan sikap peserta didik yang bersangkutan. Dengan demikian, nilai-nilai karakter yang dikembangkan di satuan pendidikan rintisan bersifat inside-out, dalam arti bahwa perilaku yang berkembang menjadi kebiasaan baik ini terjadi karena adanya

Tabel 2. Komponen Kurikulum Tingkat Satuan Pendidikan

\begin{tabular}{|l|l|l|}
\hline No & \multicolumn{1}{|c|}{ Bagian } & \multicolumn{1}{c|}{ Berisikan } \\
\hline 1 & Sampul & $\begin{array}{l}\text { Identitas, cover / halaman judul lengkap dengan alamat } \\
\text { sekolah }\end{array}$ \\
\hline 2 & Setelah halaman sampul & Kata pengantar, dan lembar pemberlakuan / pengesahan \\
\hline 3 & Daftar isi & Kerangka kurikulum secara lengkap \\
\hline 4 & Bab 1 & $\begin{array}{l}\text { Pendahuluan yang mencakup: latar belakang, prinsip } \\
\text { pengembangan kurikulum, dan tujuan penyusunan }\end{array}$ \\
\hline 5 & Bab 2 & $\begin{array}{l}\text { Tujuan pendidikan yang mencakup: tujuan satuan } \\
\text { pendidikan, visi, misi, tujuan sekolah, dan standar } \\
\text { kompetensi lulusan }\end{array}$ \\
\hline 6 & Bab 3 & $\begin{array}{l}\text { Struktur dan muatan kurikulum yang mencakup: struktur } \\
\text { kurikulum, muatan kurikulum, ketuntasan belajar, } \\
\text { remedial dan pengayaan, kriteria kenaikan kelas, kriteria } \\
\text { kelulusan, dan ketentuan pindah sekolah }\end{array}$ \\
\hline 7 & Bab 4 & $\begin{array}{l}\text { Kalender pendidikan yang mencakup: permulaan tahun } \\
\text { pelajaran baru, waktu belajar efektif, libur sekolah, dan } \\
\text { kalender sekolah }\end{array}$ \\
\hline 8 & Lampiran & $\begin{array}{l}\text { Silabus dan RPP yang biasanya menjadi dokumen } \\
\text { terpisah }\end{array}$ \\
\hline
\end{tabular}


dorongan dari dalam, adanya kesadaran bukan karena adanya paksaan dari luar. Diyakini pula oleh trainee bahwa dalam pendidikan karakter, mengetahui apa yang baik saja tidak cukup. Yang sangat penting adalah menyemaikan kebaikan dan keyakinan tersebut di hati (merasakan yang baik) dan mewujudkannya dalam tindakan, perbuatan dan/atau perilaku seluruh komunitas satuan pendidikan sebagai implementasi kurikulum (melakukan yang baik), yang dikenal dengan istilah menumbuhkan capasity building.

Di samping itu, berdasarkan hasil dari grup diskusi secara terfokus dengan trainer/fasilitator sependapat bahwa membangun keyakinan, dan sikap yang mendasari kebiasaan baik bukan usaha "sekali jadi", namun merupakan proses yang berlangsung sedikit demi sedikit secara terusmenerus dan berkelanjutan yang ditanam pada semua substansi, aktivitas/proses dan iklim pembelajaran. Begitu pula posisi kepala satuan pendidikan dan pendidik/guru sebagai pemimpin transformasional harus didorong oleh para pembina di lapangan, dalam hal ini dinas pendidikan kabupaten/kota agar mereka mampu mengembangkan substansi, proses, aktivitas dan suasana belajar yang mencerahkan, menumbuhkan inspirasi, mengembangkan kepercayaan diri, menunjukkan kepedulian, dan menggugah peserta didik untuk merumuskan atau menetapkan prinsip dan cita-cita hidup mereka masingmasing. Dengan demikian, dalam pembelajaran para pendidik senantiasa mendorong para peserta didik untuk mengidentifikasikan atau memikirkan hal-hal yang berarti atau bermakna dalam kehidupan mereka.

\section{Supervisi}

Berdasarkan hasil dari grup diskusi secara terfokus dengan trainer/fasilitator disepakati bahwa supervisi yang akan dikenakan terhadap satuan pendidikan rintisan pada dasarnya mencakup tiga hal, yaitu: 1) mensupervisi terhadap kelengkapan dan kebenaran dokumen KTSP, 2) mensupervisi terhadap pembelajaran (termasuk penilaian) sehingga perlu melakukan observasi kelas guna memastikan apakah skema lesson design telah diterapkan secara benar dan konsekuen, 3) mensupervisi yang berkait dengan pembiasaan, pembudayaan, dan aktivitas lainnya yang dirancang terjadi dalam lingkungan satuan pendidikan.

Di samping itu, disepakati pula bahwa kegiatan supervisi terhadap satuan pendidikan rintisan merupakan sebuah proses yang secara sadar, dan terencana dilakukan dengan menganut prinsip-prinsip sebagai berikut. Pertama, bahwa dalam supervisi haruslah sebuah tindakan yang mampu mengarahkan pendidik dan manajemen satuan pendidikan serta pemangku kepentingan di daerah untuk bekerja secara bersama dan bersinergi dalam merencanakan dan melaksanakan prinsip-prinsip pembelajaran yang telah dirancangnya.

Kedua, bahwa selama berinteraksi antara trainer/fasilitator (yang sekaligus berperan sebagai supervisor) dengan yang disupervisi (trainee) hendaknya terjalin kemitraan yang elegan. Dalam arti, bahwa kegiatan supervisi hendaknya tidak menimbulkan keteganganketegangan baru di antara pendidik, kepala satuan pendidikan, dan pembina lainnya dengan trainer/fasilitator. Misalnya, hasil kerjanya dihargai dan tidak berada di bawah tekanan atau ancaman serta mendiskusikan berbagai hal ketimbang terus memberikan instruksi. Karena itu, dalam hal ini kesadaran semua pihak yang terlibat kegiatan supervisi kesadaran untuk saling belajar sangat dibutuhkan dalam siklus supervisi untuk menganalisis permasalahan yang timbul.

Ketiga, trainer/fasilitator hendaknya memberi kesempatan kepada pendidik/guru untuk menganalisis permasalahan pembelajaran secara mandiri sehingga mereka akan selalu belajar cara menili performa diri sendiri, kemudian mendiskusikannya berdasarkan pemahaman dan pengalamannya kepada trainer/fasilitator.

Keempat, bahwa peningkatan kemampuan pendidik/guru akan terjadi jika proses supervisi didasarkan pada semangat hubungan kemitraan yang saling membantu daripada semata-mata menilai baik-buruk atau salah-benarnya. Meskipun penilaian dan evaluasi juga dibutuhkan dalam proses supervisi, namun kedua hal itu dipandang sebagai instrumen yang justru dapat digunakan untuk menolong pendidik dalam meningkatkan kemampuan mengajarnya. Trainer/fasilitator umumnya menyadari bahwa tujuan yang paling fundamental dari sebuah proses supervisi adalah 
menolong orang lain agar menjadi lebih baik sehingga kemampuan merancang dan melaksanakan pembelajaran itu sendiri terus berkembang.

Kelima, rasa saling percaya (trust) adalah kunci pokok dalam membangun hubungan yang lebih kooperatif antara trainee dengan trainer/ fasilitator. Diyakini bahwa rasa saling percaya hanya akan tumbuh ketika kejujuran, komunikasi yang terbuka, serta komitmen untuk meningkatkan layanan pendidikan terhadap peserta didik ke arah yang lebih baik disepakati bersama antara pendidik dan trainer/fasilitator.

Dalam mensupervisi terhadap dokumen KTSP, misalnya, berdasarkan hasil laporan kegiatan supervisi ditemukan beberapa kasus kurang tepatnya suatu komponen seperti tampak dalam Tabel 3 berikut ini.

Di pertemuan awal kegiatan supervisi telah diadakan diskusi dan interaksi secara intensif antara trainer/fasilitator dengan trainee tentang rancang bangun rencana pelaksanaan pembelajaran yang meliputi kompetensi-kompetensi dasar mana saja yang bermuatan nilai-nilai karakter dan yang akan diajarkan pada satuan waktu tertentu, bagaimana mencapai tujuantujuan pembelajaran yang ideal berdasarkan karakteristik peserta didik, prosedur apa yang akan ditempuh, strategi apa yang ditetapkan, serta melihat bagaimana pendidik memastikan bahwa apa yang akan dibelajarkannya dipahami oleh peserta didik (evaluation).

Pada tahap kedua trainer/fasilitator juga dituntut dan perlu melakukan observasi kelas untuk memastikan bahwa apa yang ditulis dalam rencana pelaksanaan pembelajaran (RPP) dilaksanakan sesuai dengan desainnya. Ketika melakukan observasi kelas, trainer/fasilitator berusaha menghindari interaksi langsung dengan pendidik. Namun, petugas cukup mengobservasi dan membuat catatan sebanyak mungkin selama proses-proses pembelajaran berlangsung. Catatan-catatan tersebut menjadi sangat penting untuk melihat kesesuaian antara RPP dengan realita. Selanjutnya, tahap terakhir adalah melakukan review terhadap kegiatan pembelajaran yang telah dilakukan pendidik. Proses

Tabel 3. Beberapa Contoh Komponen KTSP yang Perlu Disupervisi

\begin{tabular}{|l|c|l|}
\hline No & Aspek & \multicolumn{1}{c|}{ Analisis } \\
\hline 1 & RKS dan RKAS & $\begin{array}{l}\text { Umumnya hanya menggambarkan kegiatan global yang akan dilakukan } \\
\text { dalam satu tahun kalender akademik, rincian rencana aksi dan biaya } \\
\text { cenderung tidak dicantumkan. }\end{array}$ \\
\hline 2 & Visi Sekolah & $\begin{array}{l}\text { a.Dokumen pada umumnya mencantumkan visi sekolah. } \\
\text { b.Visi sekolah umumnya belum disusun bersama dengan melibatkan } \\
\text { seluruh komunitas sekolah (terutama pendidik). } \\
\text { c. Visi sekolah umumnya telah ada sejak dari dulu / sebelum KTSP, dan } \\
\text { guru umumnya cenderung tidak tahu. } \\
\text { d.Visi sekolah umumnya belum menggambarkan: 1) cita-cita yang } \\
\text { diharapkan dicapai di masa yang akan datang oleh seluruh warga } \\
\text { sekolah, 2) cita-cita masa depan yang ada dipemikiran para penyusun } \\
\text { kurikulum, dan 3) representasi dari keyakinan mengenai bagaimanakah } \\
\text { seharusnya pendidikan karakter pada sekolahnya di masa depan. } \\
\text { e.Kalimat dalam visi sekolah umumnya normatif, misalnya imtaq, unggul } \\
\text { dan berprasa umum. } \\
\text { f. Dalam kegiatan pembelajaran (penerapan silabus dan RPP) umumnya } \\
\text { tidak sejalan antara yang tertulis dalam visi dan rencana aksi } \\
\text { kenyataan } \\
\text { g.Ada kecenderungan visi sekolah disusun hanya oleh beberapa orang. }\end{array}$ \\
\hline 3 & $\begin{array}{l}\text { Pengembangan } \\
\text { Diri }\end{array}$ & $\begin{array}{l}\text { a.Sekolah umumnya mencantumkan kegiatan pengembangan diri } \\
\text { b.Kegiatan pengembangan diri umumnya belum operasional (kapan, siapa, } \\
\text { di mana, dan bagaimana menilaianya), dan hanya menyebut pramuka, } \\
\text { olah raga, bahasa daerah, iqro, seni tradisional dll }\end{array}$ \\
\hline 4 & Silabus dan \\
RPP & $\begin{array}{l}\text { Silabus dan RPP untuk setiap mata pelajaran umumnya telah } \\
\text { mengitegrasikan nilai-nilai pendidikan karakter, namun antara yang } \\
\text { tertulis dalam visi, misi, dan tujuan sekolah dengan silabus dan RPP } \\
\text { cenderung tidak ada benang merahnya, visi ke mana, silabus dan RPP ke } \\
\text { mana. }\end{array}$ \\
\hline
\end{tabular}


review dilakukan berdasarkan rekaman dan data yang diperoleh trainer/fasilitator secara langsung ketika melakukan observasi kelas, dan trainer/ fasilitator menghindari untuk menilai terlebih dahulu tetapi hanya menunjukkan tentang apa yang telah diobservasi. Jika pendidik membaca secara seksama data hasil observasi tersebut barulah didiskusikan dan dianalisis secara bersama-sama, sehingga ditemukan pada aspek mana dari pendidik yang perlu diperbaiki performanya. Hasil dari diskusi ini kemudian dijadikan catatan tersendiri oleh pendidik dan disepakati bersama untuk dijadikan bahan perbaikan pada kegiatan pembelajaran berikutnya.

Di dalam melakukan supervisi terhadap program, sasaran pencapaian titik perhatian adalah keadaan dokumen kurikulum, fisik satuan pendidikan, dan lingkungan serta budaya komunitas satuan pendidikan dengan indikator ukuran seperti contoh pada Tabel 4 berikut.

Atas dasar berbagai harapan dan temuan dalam kegiatan supervisi dapat disimpulkan bahwa manfaat supervisi dalam program pengembangan model kurikulum pendidikan karakter pada satuan pendidikan rintisan ialah: a) mengontrol kelengkapan dan kebenaran dokumen KTSP sesuai dengan nilai-nilai pendidikan karakter yang diprioritaskan dan sekaligus mengecek keselarasan dengan visi, misi, dan tujuan sekolah; b) mengontrol kegiatankegiatan dari para pelaksana nilai-nilai pendidikan karakter, yaitu bagaimana pelaksanaan tugas dan tanggungjawab mereka masing-masing; c) mengontrol adanya kemungkinan hambatanhambatan yang ditemui oleh para pelaksana dalam melaksanaakan tugasnya masing-masing; d) memungkinkan dicarinya jalan keluar terhadap hambatan-hambatan dan permasalahanpermasalahan yang ditemui; dan e) memungkinkan terlaksananya program implementasi nilainilai pendidikan karakter, secara lancar ke arah pencapaian tujuan sebagaimana yang telah ditetapkan.

\section{Simpulan dan Saran Simpulan}

Dari hasil kajian dan amatan terlibat yang telah diuraikan, dan pembahasan singkat di atas dapat disimpulkan bahwa satuan pendidikan rintisan di awal umumnya berhasil menerapkan nilai-nilai karakter yang dapat diamati secara kasat mata

Tabel 4. Contoh Indikator Keberhasilan Satuan Pendidikan Rintisan

\begin{tabular}{|c|c|c|c|}
\hline $\begin{array}{l}\text { Peduli } \\
\text { lingkungan } \\
\text { / kebersih- } \\
\text { an }\end{array}$ & $\begin{array}{l}\text { Deskripsi nilai: } \\
\text { Sikap dan } \\
\text { tindakan yang } \\
\text { selalu berupaya } \\
\text { mencegah } \\
\text { kerusakan pada } \\
\text { lingkungan alam } \\
\text { di sekitarnya dan } \\
\text { mengembangkan } \\
\text { upaya-upaya } \\
\text { untuk } \\
\text { memperbaiki } \\
\text { kerusakan alam } \\
\text { yang sudah } \\
\text { terjadi. }\end{array}$ & $\begin{array}{l}\text { Indikator sekolah: } \\
\text { - Pembiasaan memelihara kebersihan } \\
\text { dan kelestarian lingkungan sekolah. } \\
\text { - Tersedia tempat pembuangan } \\
\text { sampah dan tempat cuci tangan. } \\
\text { - Menyediakan kamar mandi dan air } \\
\text { bersih. } \\
\text { - Pembiasaan hemat energi. } \\
\text { - Membuat biopori di area sekolah. } \\
\text { - Membangun saluran pembuangan } \\
\text { air limbah dengan baik. } \\
\text { - Melakukan pembiasaan } \\
\text { memisahkan jenis sampah organik } \\
\text { dan anorganik. } \\
\text { - Penugasan pembuatan kompos dari } \\
\text { sampah organik. } \\
\text { - Penanganan limbah hasil praktik } \\
\text { (misal SMK). } \\
\text { - Menyediakan peralatan kebersihan. } \\
\text { - Membuat tandon penyimpanan air. } \\
\text { - Memrogramkan cinta bersih } \\
\text { lingkungan. }\end{array}$ & $\begin{array}{l}\text { Indikator kelas: } \\
\text { - Memelihara } \\
\text { lingkungan kelas. } \\
\text { - Tersedia tempat } \\
\text { pembuangan } \\
\text { sampah di dalam } \\
\text { kelas. } \\
\text { - Pembiasaan hemat } \\
\text { energi. } \\
\text { - Memasang stiker } \\
\text { perintah mematikan } \\
\text { lampu dan menutup } \\
\text { kran air pada setiap } \\
\text { ruangan apabila } \\
\text { selesai digunakan } \\
\text { (misal SMK). }\end{array}$ \\
\hline
\end{tabular}

Sumber: Bahan Pelatihan Pengembangan Pendidikan Budaya dan Karakter Bangsa, Pusat Kurikulum. 
langsung (tangible) seperti religius, peduli lingkungan (bersih, rapi, aman, nyaman, indah, teduh dan sejuk), disiplin, empati, kerja sama, sopan santun, ramah, senyum, salam, dan sapa sebagai indikator keberhasilanya. Di samping itu, dapat disimpulkan pula empat hal yang berkontribusi posistif dalam terwujudkan hal tersebut.

Pertama, sosialisasi dan pelatihan terhadap pemangku kepentingan satuan pendidikan rintisan di kabupaten/kota dengan materi mulai dari kebijakan pemerintah, konsepsi pendidikan karakter, perencanaan yang mencakup analisis konteks hingga tata cara penyusunan KTSP yang mengintegrasikan nilai-nilai karakter, pengelolaan budaya satuan pendidikan, implementasi dalam pembelajaran, dan supervisi pembelajaran merupakan kegiatan yang umumnya amat diperlukan oleh satuan pendidikan rintisan.

Kedua, magang yang dapat dimaknai sebagai gambaran membuka wawasan baru bagi satuan pendidikan rintisan terhadap pelaksanaan pendidikan karakter yang telah dilakukan oleh satuan pendidikan lain yang memiliki pengalaman terpetik (best practices) merupakan kegiatan yang amat dibutuhkan. Program magang yang berlandaskan pada realitas satuan pendidikan sebagai best practises dalam implementasi nilainilai pendidikan karakter yang majemuk dan unik dianggap menjadi sangat penting untuk memperoleh pengalaman langsung sebagai panduan "kehidupan" satuan pendidikan rintisan.

Ketiga, pola pendampingan oleh staf Pusat Kurikulum kepada satuan pendidikan rintisan dalam penyusunan KTSP secara periodik dan berkesinambungan yang mampu mendorong satuan pendidikan rintisan untuk mengembangkan kurikulum yang mengintegrasikan nilainilai karakter dalam arti yang luas, yaitu kurikulum sebagai produk, kurikulum sebagai program, kurikulum sebagai hasil belajar yang diinginkan, dan kurikulum sebagai pengalaman belajar bagi peserta didik merupakan bentuk layanan yang dianggap tepat. Demikian pula dalam konteks pengimplementasian pendidikan karakter dalam school based management oleh satuan pendidikan rintisan ditemukan bahwa dengan pendampingan seperti itu menjadi spirit terlaksananya seluruh aktivitas secara baik melalui kebiasaan, pembudayaan, dan situasi pembelajaran yang disengaja (deliberaty situation).

Keempat, supervisi yang mengetengahkan kemitraan dalam memberi bantuan dalam pengembangan dan mengimplementasikan KTSP yang meaningfull dengan strategi sharing of ideas, sharing of experience, memberi support, mendorong, dan menstimulasi pengembangan model satuan pendidikan rintisan merupakan kegiatan layanan dan bantuan teknis profesional dari staf Pusat Kurikulum yang nampak amat diharapkan. Kegiatan tersebut semata-mata dilihat dari sudut pandang peningkatan kualitas pembelajaran yang dilaksanakan sesuai dengan KTSP-nya dalam arti yang luas, baik di kelas maupun di luar kelas sebagai suatu sistem.

\section{Saran}

Terdapat lima saran yang dikemukakan sehubungan pengembangan model kurikulum pendidikan karakter pada satuan pendidikan rintisan.

Pertama, para pendidik, tenaga kependidikan, orang tua peserta didik, dan masyarakat diharapkan perlu menyadari betapa pentingnya pendidikan karakter sebagai sarana pembentuk pedoman perilaku, pengayaan nilai individu dengan cara menjadi figur keteladanan bagi anak didik serta mampu menciptakan lingkungan yang kondusif bagi proses pertumbuhan berupa kebersihan, kenyamanan dan keamanan, kerapihan, sopan santun, dan ramah serta keagamaan yang kokoh yang dapat membantu suasana pengembangan diri individu secara keseluruhan dari segi teknis, intelektual, psikologis, moral, sosial, estetis dan religius. Mampukah mereka menyematkan pendidikan karakter pada anak didik? Meminjam istilah Mohamad (Kompas, 30/4/2011) mampukah seorang pendidik mendidik peserta didik (cetak miring oleh penulis) memberi contoh kepatuhan untuk tidak menyusahkan orang lain, di mana pun dia berada. Contohnya, adab untuk tidak membuang sampah sembarangan, serta adab untuk tidak merokok dan menyebarkan asap kepada orang lain.

Kedua, kalau diperhatikan hasil pengembangan model satuan pendidikan rintisan pendidikan karakter nampak bahwa implementasi pendidikan karakter antarsatuan pendidikan 
rintisan tersebut kini semakin menarik, mereka memanfaatkan sumber daya secara optimal, membuat satuan pendidikan semakin elok, satuan pendidikan menjadi bersih, rapi dan nyaman serta human-friendly. Oleh karena itu, seharusnya para pemangku kepentingan pendidikan di daerah menyadari bahwa semangat pelaksanaan pendidikan karakter di satuan pendidikan rintisan semacam itu (hasil studi) sangat perlu untuk diimbaskan karena terbukti mampu melahirkan komunitas satuan pendidikan yang hiterogen dapat saling menjaga dengan saling menghargai dan membangun harmoni yang sarat dengan nilainilai karakter sehingga mendapat tempat dan kesempatan diekspresikan melalui budaya satuan pendidikan.

Ketiga, pendidikan karakter, jika dilaksanakan secara menyeluruh dan utuh sebagaimana dalam model satuan pendidikan rintisan, akan memperkuat budaya satuan pendidikan yang semakin kondusif bagi pertumbuhan setiap individu dalam komunitas satuan pendidikan. Di samping itu, menurut Siroj (Kompas, 31/7/2011) perbaikan karakter bangsa berarti merintis jalan untuk tercapainya suatu masyarakat yang baik (good governance). Budaya satuan pendidikan inilah yang sering kali luput dari pembahasan ketika para pendidik, tenaga kependidikan maupun masyarakat berbicara tentang pendidikan karakter. Pendidikan karakter tidak akan efektif jika pengembangan budaya satuan pendidikan yang berjiwa nilai karakter tidak tersentuh melalui program-program yang dirancang. Untuk itu, para pendidik, tenaga kependidikan dan komunitas satuan pendidikan mesti mengerti, menyadari, dan ikut terlibat aktif dalam mendesain pendidikan karakter berbasis budaya satuan pendidikan ini.

Keempat, apapun tujuan yang akan dicapai untuk meningkatkan atau menata ulang (merevitalisasi) pendidikan karakter di satuan pendidikan, realisasi praktis dan tujuan tersebut akan banyak tergantung dari komitmen, mutu, prakarsa, dan peran serta komunitas satuan pendidikan untuk terlibat secara aktif dalam segala aktivitas pembelajaran di satuan pendidikan, dan juga di masyarakat. Dalam rangka mempersiapkan peserta didik agar mereka bukan sekadar memahami makna karakter, maka salah satu pendekatan pembelajaran perlu dirancang secara sederhana yang mampu mengangkat tema knowing good (mengetahui yang baik), feeling good (merasakan yang baik), dan doing good (melakukan yang baik) sehingga peserta didik dibiasakan menjadi pribadi yang berkarakter baik dalam hidupnya.

Kelima, pendekatan pengimplementasian pendidikan karakter bisa dilakukan melalui berbagai macam cara, seperti melalui sosialisasi dan pelatihan kepada penyusun KTSP, kegiatan magang ke satuan pendidikan best practice, pendampingan penyusunan KTSP, dan supervisi pembelajaran sebagaimana dalam model satuan pendidikan rintisan ini. Untuk itu, yang terpenting dalam mengimplementasikan pendidikan karakter tidak cukup hanya menyentuh akal pikiran tapi juga hati setiap peserta didik agar mereka mampu menghayati dengan benar dan pada akhirnya mengambil keputusan untuk melakukan serta memiliki karakter yang baik dalam hidupnya.

\section{Pustaka Acuan}

Borg, W.R. and Gall, M.D. 1983. Educational Research: An Introduction. London: Longman, Inc.

Buchori, Mochtar. 2007. Evolusi Pendidikan Di Indonesia: Dari Kweekschool Sampai Ke IKIP, 1852-1998. Jakarta: Insist Press.

Crowl, T. K. 1996. Fundamentals of Educational Research. Chicago: Brown \& Benchmark. Horn dkk., 1973. The advanced Learner's Dictionary of Current English. Great Britain: Oxford University. hal. 733.

Departemen Pendidikan dan Kebudayaan. 1984. Pengetahuan Dasar Kuliah Kerja Nyata (K.K.N.). Jakarta: Universitas Indonesia.

Departemen Pendidikan Nasional. 2003. Undang-Undang Republik Indonesia Nomor 20 Tahun 2003 tentang Sistem Pendidikan Nasional. Jakarta.

Fairclough, Nourman. 1997. Critical Discourse Analisis: The Crutical Study of Language. London-New York: Longman. 
Grandiosa, Roffi. Education in Building a Character. http://hubpages.com/hub/Education-in-Building-aCharacter. diunduh 1 April 2011 pukul13.30.

Guralnik, David Bernard. 1986. Webster's New World Dictionary of the American Language. New York: Prentice Hall Press.

http://karakterbangkit.blogspot.com/2009/03/pendidikan-karakter-knowing-good-loving.html. diunduh 13 April pukul 08.30.

http://www.ascd.org. diunduh 6 April 10.45.

http://www.damandiri.or.id/file/abdwahidchairulahunairbab2.pdf. Diunduh 3 April 2011 pukul 13.30. http://www.thefreedictionary.com/social+function. Diunduh 3 April 2011 pukul 14.00.

Koesoema A, Doni. 2010. Pendidikan Karakter, Strategi Mendidik Anak di Zaman Global (Cetakan kedua, edisi revisi dari 2007). Jakarta: Grasindo.

Lickona,Thomas. 1992. Educating for Character: How Our Schools Can Teach Respect and Responsibility. New York: Bantam Doubleday Dell Publishing Group Inc.

Lickona, Thomas. 2004. Character Matters: How to Help Our Children Develop Good Judgment, Integrity, and Other Essential Virtues (Touchstone / Simon \& Schuster, 2004).

Macionis, John J. 1997. Sociology. Publisher: Prentice Hall.

Mendiknas. 2010. Penerapan Pendidikan Karakter Dimulai SD. http://antaranews.com/berita/ 1273933824/mendiknas, Sabtu, 15 Mei 2010. diunduh 31 Maret 2011.

Mohamad, Kartono. Adab.Kompas, Sabtu, 30 April 2011.

Neufeld, Victoria (Editor in Chief) \& David B. Guralnik (Editor in Chief Emeritus). 1991. Webster New World Dictionary, Third College Edition. Prentice Hall.

Park, N., Peterson, C., dan Seligman, M. E. P. 2004. Strengths of Character and Well-Being. Journal of Social and Clinical Psychology Vol.23, No. 5, pp. 603-619. http://proquest.umi.com/ pqdweb?did $=737635361 \&$ sid $=3 \& \mathrm{Fmt}=4 \&$ clientId $=45625 \& R Q T=309 \& V$ Name $=P Q D$. Diunduh 29 Maret 2011.

Pemerintah Republik Indonesia. 2010. Kebijakan Nasional Pembangunan Karakter Bangsa Tahun 20102025 (draft grand design).

Paterson, Christopher and Seligman, Martin E.P. 2004. Character Strengths and Virtues : A Handbook and Classification. Oxford University Press.

Pusat Bahasa, Departemen Pendidikan Nasional. 2005. Kamus Besar Bahasa Indonesia, Edisi Ketiga. Jakarta: Balai Pustaka.

Pusat Kurikulum. 2010a. Bahan Pelatihan: Penguatan Metodologi Pembelajaran Berdasarkan NilaiNilai Budaya untuk Membentuk Daya Saing dan Karakter Bangsa Pengembangan Pendidikan Budaya dan Karakter Bangsa. Jakarta: Pusat Kurikulum, Balitbang, Kemdiknas. . 2010b. Desain Model (draft September 2010): Satuan Pendidikan Rintisan Implementasi Pendidikan Budaya dan Karakter Bangsa, Kewirausahaan dan Ekonomi Kreatif dengan Pendekatan Belajar Aktif untuk Membangun Daya Saing dan Karakter Bangsa (belum diterbitkan). Jakarta: Pusat Kurikulum, Badan Penelitian dan Pengembangan. . 2010c. Program Kerja Pusat Kurikulum Tahun Anggaran 2010. Jakarta: Puskur, Balitbang, Kemdiknas.

Simamarta, 1983: ix - xii. http://kadipatentecnology.blogspot.com/2010/11/definisi-model-dansimulasi.html. diunduh 2 April 2011 pukul 10.30.

Siroj, Said Aqil, Renungan Puasa: Ramadhan Menuju Karakter Bangsa, Kompas, Minggu 31 Juli 2011. Soedarsono, Soemarno. 2004. Character Building Membentuk Watak. Jakarta: Elex Media Komputindo. Sudjana, Nana \& Ibrahim. 1989. Penelitian \& Penilaian Pendidikan. Bandung: Sinar Baru.

Suyanto. http://www.mandikdasmen.depdiknas.go.id/web/pages/urgensi.html. diunduh 1 April 2010. Pukul 13.00.

Suparlan di http://www.fisdk12.net/ww/faculty/mrsgruener.html. diunduh 30 Maret 2011 pukul 15.30. 
Sutjipto. 2009. Dinamika Pengembangan Kurikulum Tingkat Satuan Pendidikan. Jurnal Pendidikan dan Kebudayaan. Volume 15, Edisi Khusus II, Oktober 2009. Jakarta: Balitbang, Kemdiknas.

Tim Pendidikan Karakter, Kemdiknas. 2010. Grand Design Pendidikan Karakter (draft). Jakarta: Kemdiknas.

Tim Puslitjaknov. 2008. Metode Penelitian Pengembangan. Jakarta: Pusat Penelitian Kebijakan dan Inovasi Pendidikan Badan Penelitian dan Pengembangan, Departemen Pendidikan Nasional. 